\title{
Update and New Insights on Future Cancer Drug Candidates From Plant-Based Alkaloids
}

\author{
Mounir Tilaoui *, Hassan Ait Mouse and Abdelmajid Zyad \\ Experimental Oncology and Natural Substances Team, Cellular and Molecular Immuno-pharmacology, Faculty of Sciences and \\ Technology, Sultan Moulay Slimane University, Beni-Mellal, Morocco
}

OPEN ACCESS

Edited by:

Essa M. Saied,

Humboldt University of Berlin,

Germany

Reviewed by:

Gamal Eldein Fathy Abd-Ellatef Abd-

Elrahman,

National Research Centre, Egypt

Maha Mohamed Saber-Ayad,

University of Sharjah, United Arab

Emirates

Shamshad Alam,

University at Buffalo, United States

*Correspondence:

Mounir Tilaou

mounir.tilaoui@gmail.com

Specialty section:

This article was submitted to Pharmacology of Anti-Cancer Drugs,

a section of the journal

Frontiers in Pharmacology

Received: 15 June 2021 Accepted: 23 November 2021

Published: 16 December 2021

Citation:

Tilaoui M, Ait Mouse $H$ and Zyad $A$ (2021) Update and New Insights on Future Cancer Drug Candidates From

Plant-Based Alkaloids.

Front. Pharmacol. 12:719694.

doi: 10.3389/fphar.2021.719694
Cancer is a complex multifactorial disease that results from alterations in many physiological and biochemical functions. Over the last few decades, it has become clear that cancer cells can acquire multidrug resistance to conventional anticancer drugs, resulting in tumor relapse. Thus, there is a continuous need to discover new and effective anticancer drugs. Natural products from plants have served as a primary source of cancer drugs and continue to provide new plant-derived anticancer drugs. The present review describes plant-based alkaloids, which have been reported as active or potentially active in cancer treatment within the past 4 years (2017-2020), both in preclinical research and/or in clinical trials. In addition, recent insights into the possible molecular mechanism of action of alkaloid prodrugs naturally present in plants are also highlighted.

Keywords: cancer, plant-based alkaloids, preclinical research, molecular mechanism, clinical trials

\section{INTRODUCTION}

Cancer remains a leading cause of death worldwide. The survival rate, morbidity, recurrence, and poor prognosis of the disease have been the major challenges for decades in traditional nonsurgical cancer therapy regimens, including chemotherapy and radiotherapy (Zhang et al., 2020d). Nevertheless, the survival rate of patients diagnosed with cancer, particularly those in advanced stages, remains at very low levels due to drug resistance, high toxicity, and other long-term side effects of these treatments (Zhang et al., 2020d; Zhang et al., 2020a). This has encouraged scientists to search for more effective strategies and discover new anticancer drugs.

Natural products, especially those from plants, have been an extraordinarily important source for new drug discovery over the past decades (Berdigaliyev and Aljofan, 2020). At present, plant-based drugs are becoming a major source of cancer treatment (Rahman et al., 2020). Many of them have demonstrated significant anti-tumor effects, such as flavonoids (Khan et al., 2020), phenylpropanoids (Hematpoor et al., 2018), lactones (Tilaoui et al., 2014), taxanes, epipodophyllotoxins, and alkaloids (Zishan et al., 2017). In this context, there have been many studies on the anticancer activity of alkaloids due to their higher specificity, stronger effectiveness, and lower toxicity (Lu et al., 2012). This review mainly focuses on the recent cumulative preclinical research and ongoing clinical trials on alkaloids originating from plants that have been reported as effective or potentially effective in cancer treatment, with emphasis on their molecular mechanisms of action. This may provide a deep understanding of the signaling pathways to identify and develop a safe novel lead compound that selectively targets cancer cells and improves therapeutic applications for cancer treatment and prevention. The literature search was performed through the PubMed database to identify recent published original research between 2017 and 2020 . 
<smiles></smiles>

FIGURE 1 | Basic structure of alkaloids.

\section{ALKALOIDS IN THE PLANT KINGDOM}

Alkaloids are a widespread class of secondary metabolites that have animal, microbial, and plant origins. They contain a nitrogen atom and a ring structure. The position of the nitrogen atom in the carbon ring varies with different alkaloids (Figure 1). Alkaloids are predominantly derived from simple amino acid precursors, such as tyrosine, phenylalanine, tryptophan, ornithine, arginine, or lysine. Today, more than 20,000 compounds are known to encompass a large variety of chemical structures with different functional groups (Table 1), and approximately 12,000 different alkaloids have been identified in the plant kingdom, mainly in higher plants, and are distributed into various classes based on their chemical structures, biosynthetic pathways, and biological activities (Dey et al., 2020). Furthermore, many alkaloids exhibit a wide range of biological activities, including antimicrobial, antimalarial, antifungal, and anticancer effects (Debnath et al., 2018). In fact, many plantderived alkaloids have been successfully approved as chemotherapeutic drugs by the US Food and Drug Administration (FDA), such as vinblastine, which interacts with tubulin to interfere with the cell cycle (Li et al., 2007; Choudhari et al., 2020), and camptothecin, a known potent topoisomerase I inhibitor (Huang et al., 2007).

\section{ANTICANCER PLANT-BASED ALKALOIDS: PRECLINICAL RESEARCH}

\subsection{Annona muricata L Alkaloids}

The alkaloids isolated from the root of Annona muricata $\mathrm{L}$ are traditionally used in Indonesia to treat various diseases. An unreported benzylisoquinoline alkaloid, (+)-xylopine 5, was isolated from this plant-based source and demonstrated significant cytotoxic effects compared to the four known alkaloids (coclaurine, reticuline, argentinine, and atherospeminine) against the human suspension cancer cell line (HL-60 leukemia cells) and two human cancer cell lines (A549 lung cancer cells and HepG2 liver cancer cells) with $\mathrm{IC}_{50}$ values ranging from 20 to $80 \mu \mathrm{M}$ (Nugraha et al., 2021). According to the US National Cancer Institute, a natural compound has potent anticancer activity if it has an $\mathrm{IC}_{50}$ value around or below $10 \mu \mathrm{M}$ or $4 \mu \mathrm{g} / \mathrm{ml}$ (Boik 2001; Kuete and Efferth 2015; Kuete et al., 2018).

TABLE 1 | Functional groups of plant-based alkaloids.

Alkaloid

Nitidine chloride

Sophoridine

Palmatine
Structure<smiles>COc1cc2c[n+](C)c3c4cc5c(cc4ccc3c2cc1OC)OCO5</smiles>

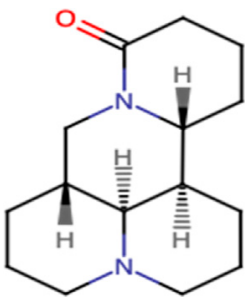<smiles>COc1cc2c(cc1OC)-c1cc3ccc(OC)c(OC)c3c[n+]1CC2</smiles>

Functional group

Arene

Benzene ring

Acetal

Ether

Amine, tertiary

Carboxamide

Carboxamide, tertiary

Lactam

Carbonyl

Arene

Benzene ring

Ether 
TABLE 1 | (Continued) Functional groups of plant-based alkaloids.

Alkaloid

Aleutianamine

Nuciferine

Theobromine

Berberine

Homoharringtonine
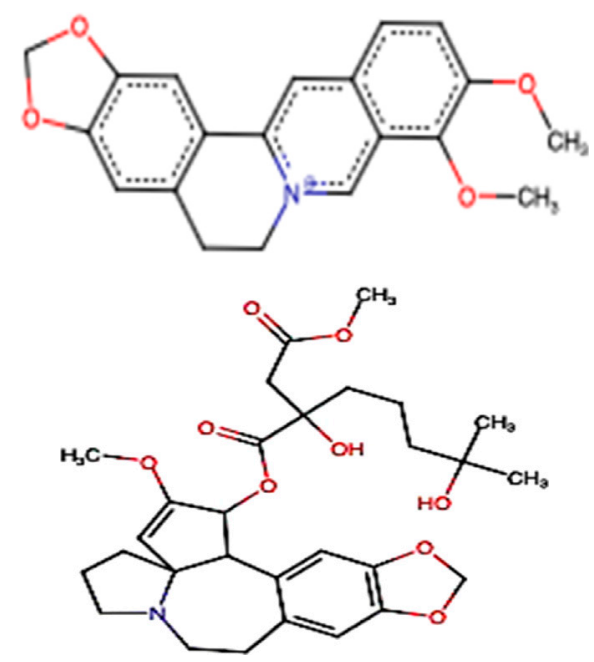

Functional group

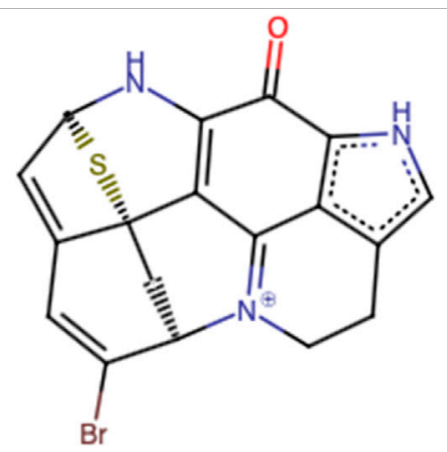<smiles>COc1cc2c3c(c1OC)-c1ccccc1C[C@H]3N(C)CC2</smiles>

Arene

Azaarene

Heteroarene

Amine

Amine, secondary

Amine, tertiary

Arene

Benzene ring

Acetal

Ether

Arene

Benzene ring

Alkene

Amine

Amine, tertiary

Acetal

Alkanol

Carbonyl

Enol ether

Ester (carboxylate ester)

Ether 
TABLE 2 | Summary of recent preclinical and clinical trials of plant-based alkaloids on cancer treatment.

\begin{tabular}{|c|c|c|c|c|}
\hline \multirow[t]{2}{*}{ Alkaloid type } & \multicolumn{2}{|c|}{ Preclinical research } & \multirow[t]{2}{*}{ Clinical trial } & \multirow[t]{2}{*}{ Reference } \\
\hline & In vitro studies & In vivo studies & & \\
\hline Nitidine chloride & $\begin{array}{l}\text { Liver cancer: Huh7 }\left(\mathrm{IC}_{50}=5.006 \mu \mathrm{M}\right) \text {; } \\
\text { SMMC7721 }\left(\mathrm{IC}_{50}=1.332 \mu \mathrm{M}\right)\end{array}$ & $\begin{array}{l}\text { Liver cancer: Tumor volume decreased in } \\
\text { BALB/c nude mice injected with SMMC7721 }\end{array}$ & Not applicable & Xiong et al. (2019) \\
\hline Sophoridine & $\begin{array}{l}\text { Lung Cancer: } \mathrm{H} 460\left(\left(\mathrm{IC}_{50}=73.49 \mu \mathrm{g} / \mathrm{ml} /\right.\right. \\
24 \mathrm{~h}) ;(\mathrm{IC} 50=53.52 \mu \mathrm{g} / \mathrm{ml} / 48 \mathrm{~h})) ; \text { Lewis }\left(\left(\mathrm{IC}_{50}\right.\right. \\
=64.95 \mu \mathrm{g} / \mathrm{ml} / 24 \mathrm{~h}) ;(\mathrm{IC} 50=40.49 \mu \mathrm{g} / \\
\mathrm{ml} / 48 \mathrm{~h})) \\
\text { Gastric cancer: SGC7901 }\left(\mathrm{IC}_{50}=3.52 \mu \mathrm{M} /\right. \\
12 \mathrm{~h}) ; \mathrm{AGS}\left(\mathrm{IC} \mathrm{C}_{50}=3.91 \mu \mathrm{M} / 12 \mathrm{~h}\right) ; \mathrm{GES}-1\left(\mathrm{IC}_{50}\right. \\
=51.40 \mu \mathrm{M} / 12 \mathrm{~h})\end{array}$ & $\begin{array}{l}\text { Lung cancer: } 15 \text { or } 25 \mathrm{mg} / \mathrm{kg} \text { suppressed } \\
\text { the tumor growth and upregulated the } \\
\text { expression of CD } 86 / \mathrm{F} 4 / 80 \text { in tumor tissues in } \\
\text { the Lewis-bearing mice model }\end{array}$ & Not applicable & $\begin{array}{l}\text { Peng et al. (2020) } \\
\text { Zhao et al. (2021) }\end{array}$ \\
\hline Palmatine & $\begin{array}{l}\text { Colon cancer: HT-29 }\left(\mathrm{IC}_{50}=68.3 \mu \mathrm{M}\right) \text {; SW- } \\
480\left(\mathrm{IC}_{50}=72.6 \mu \mathrm{M}\right) \\
\text { Ovarian cancer: } \mathrm{IC}_{50} \text { values ranging from } 5.5 \\
\text { to } 7.9 \mu \mathrm{M} \\
\text { Melanoma: A375 }\left(\mathrm{IC}_{50}>200 \mu \mathrm{g} / \mathrm{ml}\right) ; \mathrm{G} 361 \\
\left(\mathrm{IC}_{50}=119.98 \mu \mathrm{g} / \mathrm{ml}\right) ; \mathrm{SK}-\mathrm{MEL}-3(\mathrm{IC} 50= \\
88.04 \mu \mathrm{g} / \mathrm{ml}) \\
\text { Prostate cancer: DU145 }\left(\mathrm{IC}_{50}=10 \mu \mathrm{g} / \mathrm{ml}\right) \\
\text { Gastric cancer: MKN-45 }\left(\mathrm{IC}_{50}=332.43 \mu \mathrm{M}\right)\end{array}$ & $\begin{array}{l}\text { Colon cancer: Gavage once a day with } \\
33.75,67.5 \text {, and } 135 \mathrm{mg} / \mathrm{kg} \text { inhibits the } \\
\text { growth of HCT-116 xenograft tumors; }-10 \\
\text { to } 20 \mathrm{mg} / \mathrm{kg} / \text { day decreased tumor numbers } \\
\text { in the small intestine and colon in ApcMin'+ } \\
\text { mice }\end{array}$ & Not applicable & $\begin{array}{l}\text { Johnson-Ajinwo } \\
\text { et al. (2019) } \\
\text { Tuzimski et al. } \\
\text { (2021) } \\
\text { Hambright et al. } \\
\text { (2015) } \\
\text { Liu et al. (2020a) } \\
\text { Ma et al. (2016) } \\
\text { Yu et al. (2020) }\end{array}$ \\
\hline Aleutianamine & $\begin{array}{l}\text { Pancreatic cancer: PANC-1 }\left(\mathrm{IC}_{50}=25 \mathrm{nM}\right) \\
\text { Colon cancer: HCT-116 }\left(\mathrm{IC}_{50}=1 \mu \mathrm{M}\right)\end{array}$ & Not applicable & Not applicable & Zou et al. (2019) \\
\hline Nuciferine & 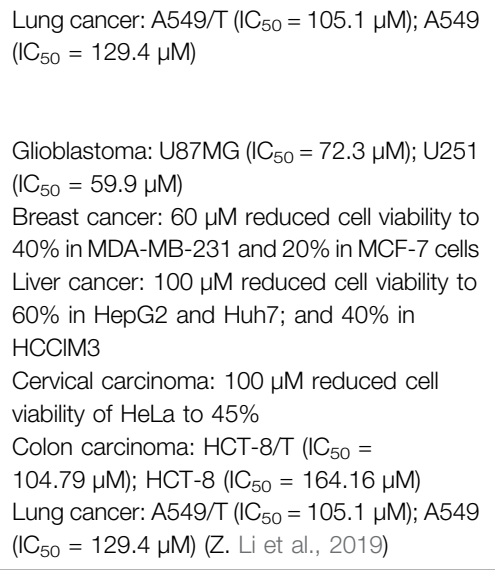 & $\begin{array}{l}\text { Lung cancer: Moderate tumor growth } \\
\text { inhibition in the A549/T xenograft model in } \\
\text { BALB/c-nu/nu mice treated with } 7.5 \mathrm{mg} / \mathrm{kg} / \\
\mathrm{ip} / 3 \text { days for } 27 \text { days } \\
\text { Glioblastoma: Inhibition of tumor volume } \\
\text { growth in glioblastoma xenograft BALB/c } \\
\text { nude mouse models }\end{array}$ & Not applicable & $\begin{array}{l}\text { Liu et al. (2020b) } \\
\text { Kang et al. (2017) }\end{array}$ \\
\hline Methylxanthines & $\begin{array}{l}\text { Breast cancer: MDA-MB-231 }\left(\mathrm{IC}_{50}>100 \mu \mathrm{M} \text {, }\right. \\
\text { Theophyline) } \\
\text { Gastric cancer: MGC-803 }\left(\mathrm{IC}_{50}=4 \mathrm{mM} \text {, }\right. \\
\text { Caffeine); MGC-803 }\left(\mathrm{IC}_{50}=8 \mathrm{mM} \text {, }\right. \\
\text { Theophylline) } \\
\text { Oral epidermoid carcinoma: } \mathrm{KB}\left(\mathrm{IC}_{50}=\right. \\
2.5 \mathrm{mM} / 48 \mathrm{~h}) \\
\text { Lung cancer: } \mathrm{H} 1355\left(\mathrm{IC}_{50}=2.5 \mathrm{mM} / 48\right) \\
\text { Melanoma: GLL-1 }\left(\mathrm{IC}_{50}=2.5 \mathrm{mM} / 48\right) \\
\text { Colon carcinoma: } \mathrm{HCT}-116\left(\mathrm{IC}_{50}=\right. \\
500 \mu \mathrm{M} / 72 \mathrm{~h})\end{array}$ & $\begin{array}{l}\text { Breast cancer: Not applicable } \\
\text { Gastric cancer: BALB/c nude mice injected } \\
\text { intraperitoneally with caffeine }(4 \mathrm{mM}) \text { or } \\
\text { theophylline }(8 \mathrm{mM}) \text { results in reducing tumor } \\
\text { size }\end{array}$ & $\begin{array}{l}\text { Breast cancer: Study phase } \\
\text { not applicable } \\
\text { (NCT03482401) }\end{array}$ & $\begin{array}{l}\text { Hashemi-Niasari } \\
\text { et al. (2018) } \\
\text { Liu et al. (2019a) } \\
\text { Ávila-Gálvez et al. } \\
\text { (2019) } \\
\text { Caraglia et al. (2002) } \\
\text { Beklen et al. (2021) }\end{array}$ \\
\hline \multirow[t]{2}{*}{ Berberine } & $\begin{array}{l}\text { Colon cancer: SW620 }\left(\mathrm{IC}_{50}=54.41 \mu \mathrm{M} / 48 \mathrm{~h}\right) \\
\text { LoVo }\left(\mathrm{IC}_{50}=78.66 \mu \mathrm{M} / 48 \mathrm{~h}\right)\end{array}$ & $\begin{array}{l}\text { Colon cancer: Dose of } 10 \mathrm{mg} / \mathrm{kg} / \mathrm{qd} / \mathrm{ip} / \mathrm{for} \\
2 \text { weeks reduces tumor volume in Balb/c } \\
\text { mice }\end{array}$ & $\begin{array}{l}\text { Colorectal adenoma: Phase } \\
\text { II, Phase III; NCT02226185 }\end{array}$ & Zhao et al. (2017) \\
\hline & $\begin{array}{l}\text { Breast cancer: BT549 }\left(\mathrm{IC}_{50}=\right. \\
16.575-1.219 \mathrm{mg} / \mathrm{ml}) ; \mathrm{MDA}-\mathrm{MB}-231\left(\mathrm{IC}_{50}=\right. \\
18.525-6.139 \mathrm{mg} / \mathrm{ml})\end{array}$ & $\begin{array}{l}\text { Breast cancer: Oral dose }(100 \mathrm{mg} / \mathrm{kg}) / \\
3 \text { days inhibited tumor growth and increased } \\
\text { caspase- } 9 \text { levels in MDA-MB- } 231 \text { in the } \\
\text { BALB/c mouse-xenograft model; }-0.1 \% \text { in } \\
\text { the drinking water/day during } 6.6 \mathrm{w} \\
\text { promoted the antitumoral activity in female } \\
\text { Balb/c; }-50 \mathrm{mg} / \mathrm{kg} / \text { po decreased the tumor } \\
\text { size in rats }\end{array}$ & & Kim et al. (2018) \\
\hline
\end{tabular}


TABLE 2 | (Continued) Summary of recent preclinical and clinical trials of plant-based alkaloids on cancer treatment.

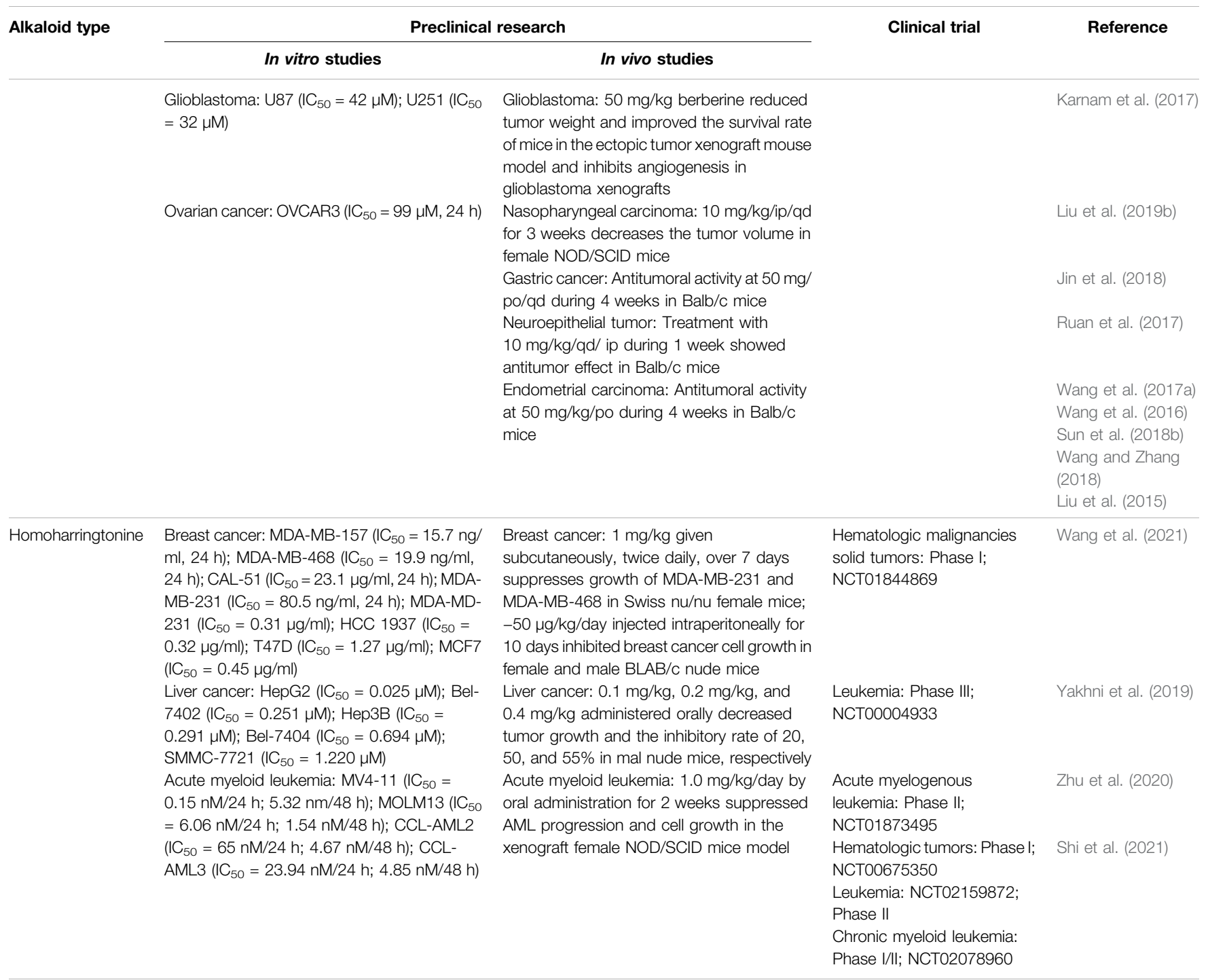

$I_{50}$ : Half maximal inhibitory concentration.

aStudy phase not applicable describes trials without Food and Drug Administration (FDA)-defined phases.

NCT: Clinical trial umber.

\subsection{Nitidine Chloride}

Nitidine chloride, a major active ingredient isolated from the roots of the traditional Chinese medicinal herb Zanthoxylum nitidum (Roxb) DC, has been demonstrated to have anticancer effects on human malignant tumors, including HCC (Table 2). Xiong et al., 2019 demonstrated that nitidine chloride inhibits proliferation by $\mathrm{G} 2 / \mathrm{M}$ phase arrest and induces apoptosis (Figure 2) of HCC cells in vitro with an $\mathrm{IC}_{50}$ of $1.332 \mu \mathrm{M} / \mathrm{L}$ in SMMC7721 cells and $5.006 \mu \mathrm{M} / \mathrm{L}$ in Huh7 cells. In addition, it has been shown that nitidine chloride exerts antimetastatic effects by suppressing cell migration and invasion (Figure 2). In in vivo, nitidine chloride has been shown to decrease the tumor volume with a total of 297 circRNAs differentially expressed between the nitidine chloride-treated and nitidine chloride-untreated groups. Thus, circRNAs may play an important role in the progression of hepatocellular carcinoma (Xiong et al., 2019).

\subsubsection{Nitidine Chloride Safety}

Importantly, nitidine chloride has a well-established safety; it shows no nephrotic and no hepatic toxicity at a dose of $10 \mathrm{mg} / \mathrm{kg}$ in mouse (Kim et al., 2017, 3). Also, no acute toxicity was observed within CD female mice treated intraperitoneally with doses ranged from 0.1 to $20 \mathrm{mg} / \mathrm{kg}\left(\mathrm{LD}_{50}=20 \mathrm{mg} / \mathrm{kg}\right)$ (Bouquet et al., 2012).

\subsection{Sophoridine}

Sophoridine is a quinolizidine-based alkaloid extracted from the leaves and stems of Euchresta japonica Benth and Sophora alopecuroides L. and roots of Sophora alopecuroides Ait. plants. It is known to exhibit various pharmacological effects, including antiinflammatory, anti-anaphylactic, antiarrhythmic, and antiviral activities (ur Rashid et al., 2020). Sophoridine has been shown to exert potent cytotoxic activity against gastric cancer cells (Table 2) by suppressing the polarization of M2 tumor-associated macrophages, 

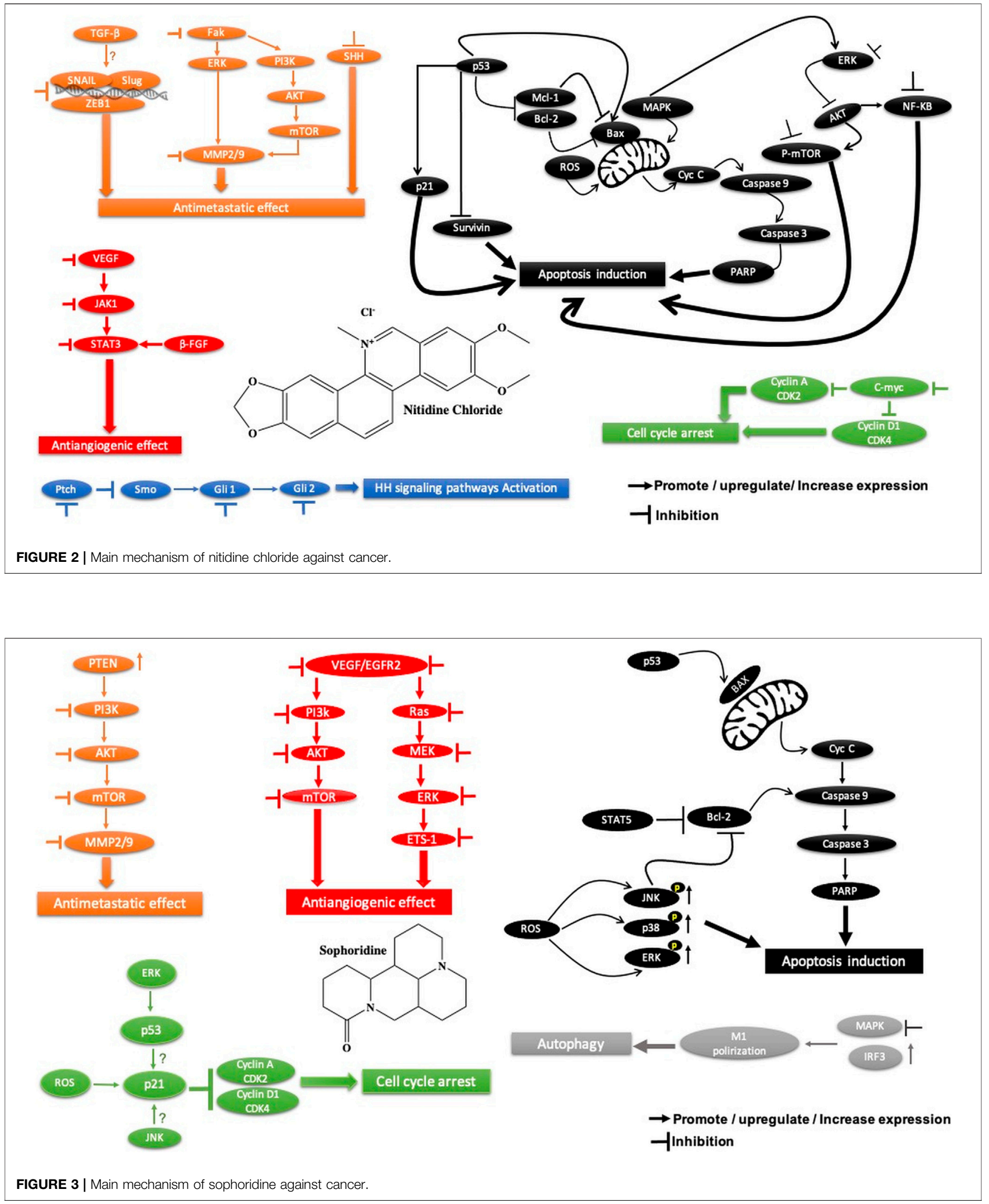


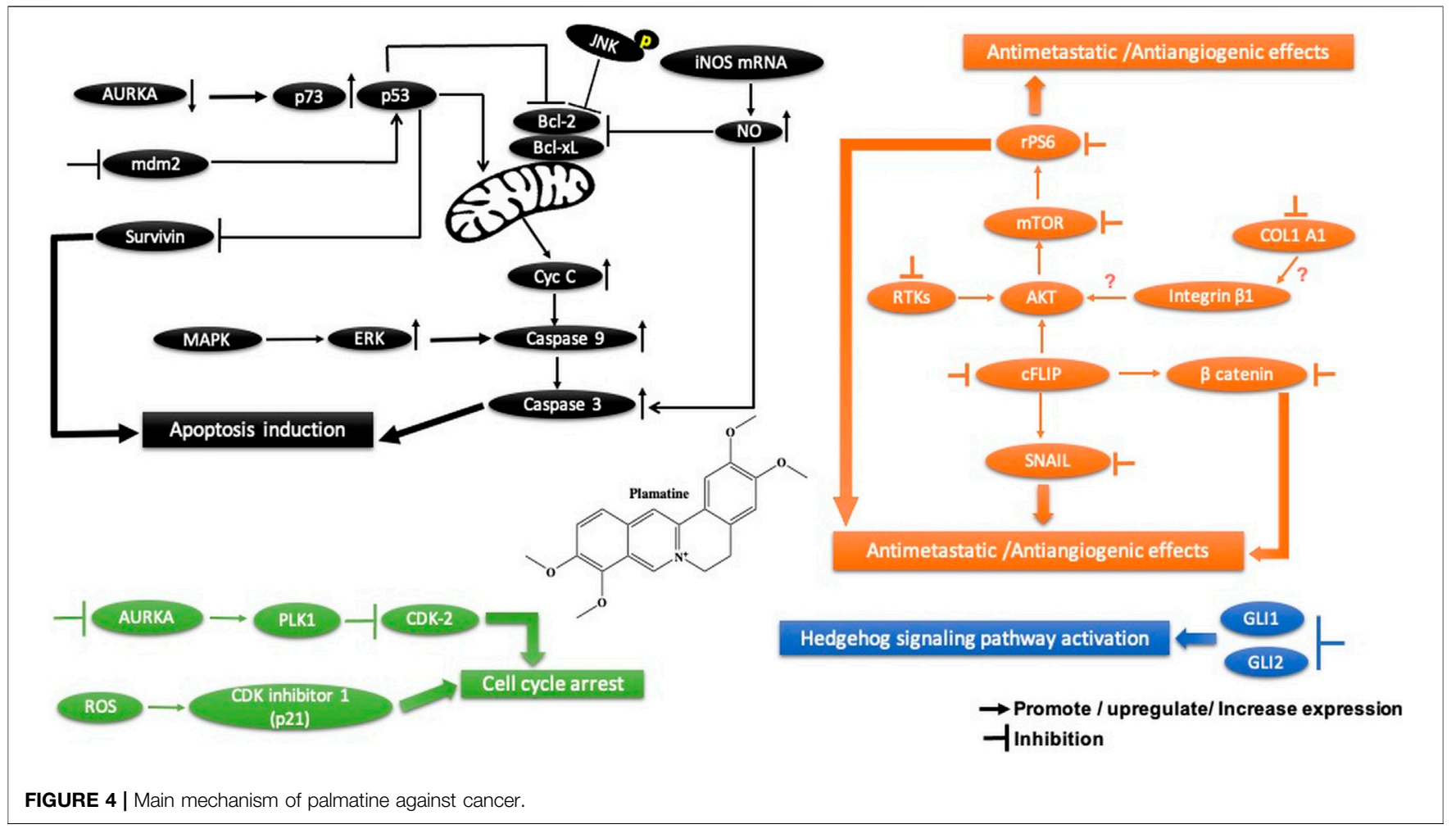

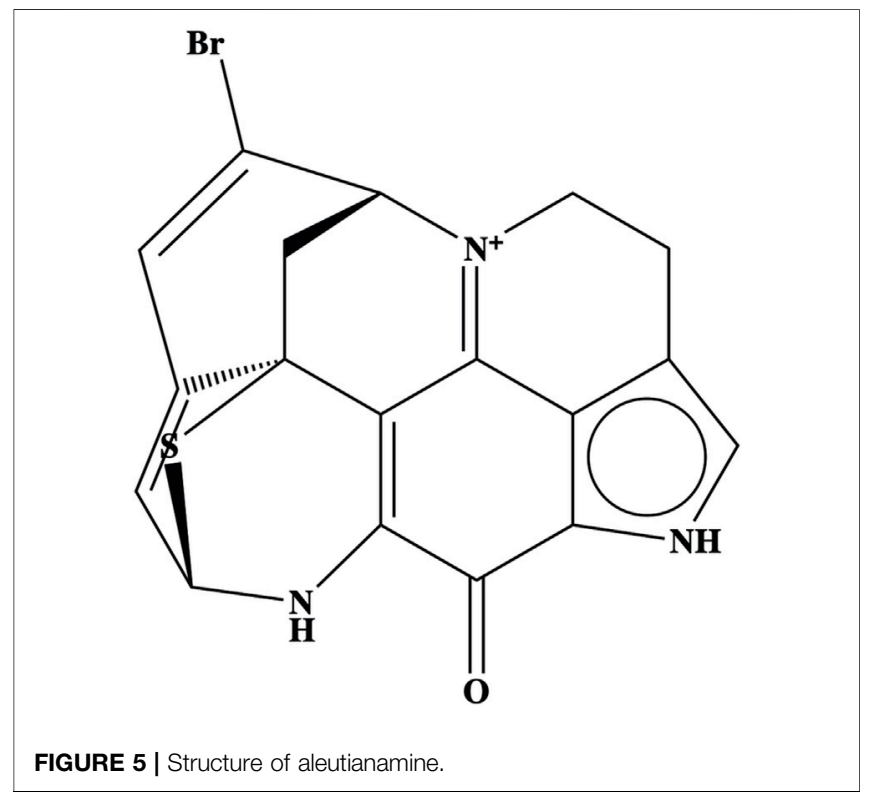

increasing the polarization of M1-tumor-associated macrophages through the TLR4/IRF3 pathway, and inhibiting tumor-associated macrophage infiltration by downregulating the expression of CCR2 in the gastric cancer microenvironment, subsequently enhancing the cytotoxic function of $\mathrm{CD}^{+} \mathrm{T}$ cells and alleviating $\mathrm{CD}^{+} \mathrm{T}$ cell function exhaustion (Zhuang et al., 2020) (Figure 3). Another study showed that sophoridine significantly inhibits survival, invasion, and migration of gastric cancer cells by enhancing estrogen-related receptor gamma expression, which leads to the degradation of $\beta$-catenin. Furthermore, it induces $G 2 / \mathrm{M}$ cell cycle arrest by inhibiting double-stranded DNA break repair and enhances the efficacy of cisplatin in gastric cancer cells (Peng et al., 2020). Therefore, sophoridine may be a promising candidate for human gastric cancer treatment. In terms of potential toxicity, there is, however, no safety assessment of sophoridine has been reported yet to the best of our knowledge.

\subsection{Palmatine}

Palmatine, another alkaloid from Rutidea parviflora, has been shown to exhibit strong cytotoxic activity against ovarian cancer cell lines with $\mathrm{IC}_{50}$ values ranging from 5.5 to $7.9 \mu \mathrm{M}$ (Table 2). Importantly, palmatine is less cytotoxic toward immortalized human ovarian epithelial cells. Furthermore, it induces apoptosis by increasing caspase 3-7 activity and poly(ADP-ribose) polymerase cleavage in OVCAR-4 cancer cells (Johnson-Ajinwo, Richardson, and Li 2019) (Figure 4). Additionally, palmatine has been shown to inhibit proliferation and migration while inducing apoptosis by inhibiting the survivin protein in pancreatic cancer cells, either alone or in combination with the conventional drug gemcitabine. Chakravarthy et al. linked these effects to the suppression of glutamine-mediated changes in the GLI signaling pathway in pancreatic cancer cells, which thereby induces apoptosis with simultaneous inhibition of survivin and collagen type 1 alpha 1 (Chakravarthy et al., 2018, 1).

\subsubsection{Palmatine Safety}

On the evidence available, palmatine appears to be a safe drug in animal models. In mice, the acute toxicity showed that the $\mathrm{LD}_{50}$ is 


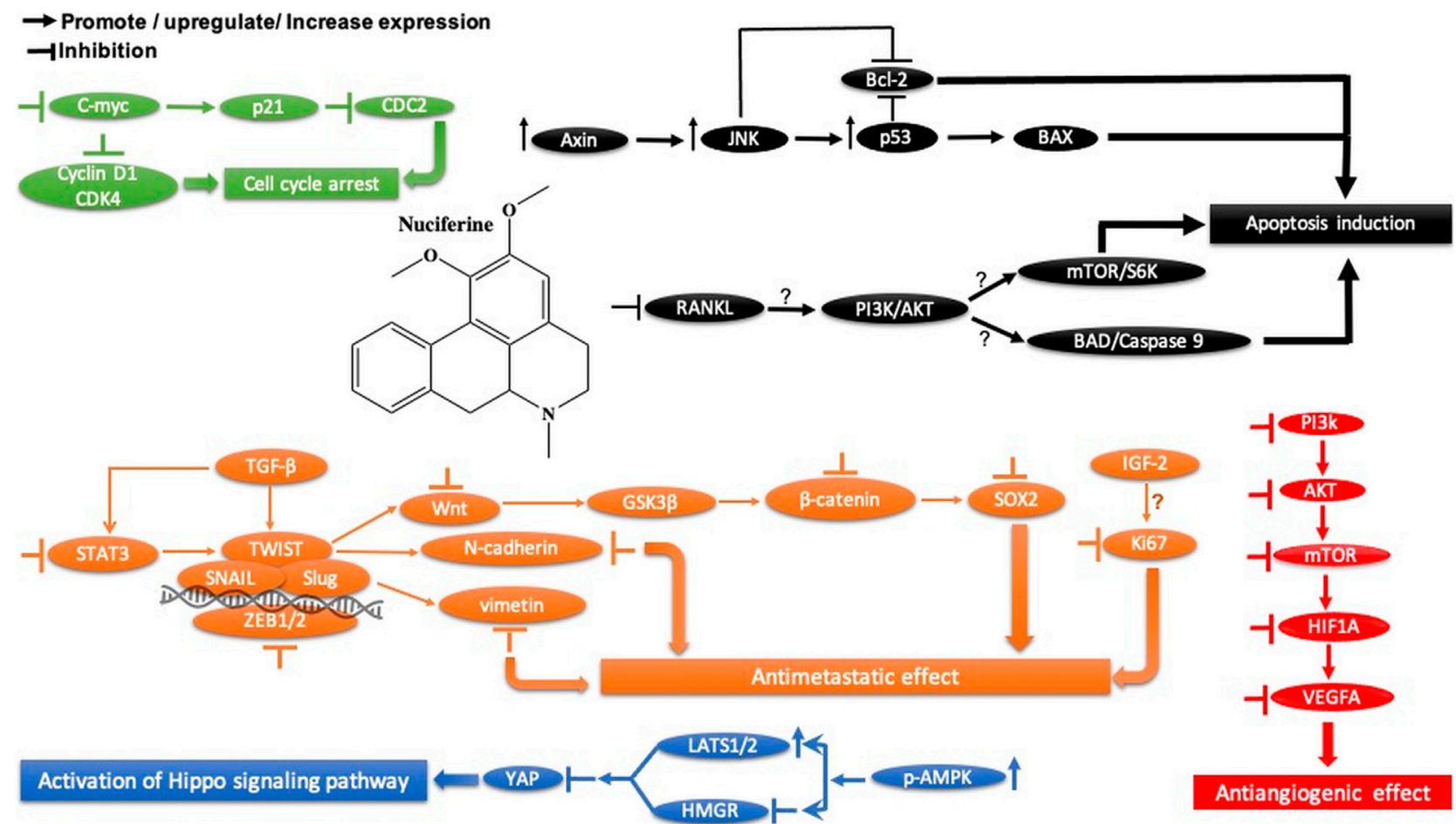

FIGURE 6 | Main mechanism of nuciferine against cancer.

$1,533.68 \mathrm{mg} / \mathrm{kg}$. In the subchronic toxicity, no adverse effects, no mortality, and no morbidity were revealed in rats treated with $156 \mathrm{mg} / \mathrm{kg}$ for 90 days (Yi et al., 2013).

\subsection{Aleutianamine}

Aleutianamine (Figure 5), a new class of pyrroloiminoquinone alkaloids from Alaska's deep ocean, was found to exhibit potent and selective cytotoxicity toward solid tumor cell lines, including pancreatic cancer (PANC-1), with an $\mathrm{IC}_{50}$ of $25 \mathrm{nM}$ and colon cancer (HCT-116) with an $\mathrm{IC}_{50}$ of $1 \mu \mathrm{M}$ (Zou et al., 2019). In terms of safety, to our knowledge, no scientific reports about the potential toxicity of aleutianmine have been investigated.

\subsection{Nuciferine}

Nuciferine, extracted from the leaves of Nelumbo nucifera Gaertn, has been shown to inhibit cell migration and angiogenesis by inducing apoptosis and G2 cell cycle arrest in glioblastoma cells (U87MG and U251). These effects are triggered by the decrease in Slug expression through the SOX2-AKT and STAT3 signaling pathways (Figure 6). Interestingly, it showed less cytotoxicity in normal human cells (HUVECs, LO2, and HK2). In in vivo, nuciferine exhibited significant tumor control in glioblastoma xenograft $\mathrm{BALB} / \mathrm{c}$ nude mouse models. Therefore, nuciferine could be a potential drug for the treatment of glioblastoma. In addition, nuciferine has been found to have potent cytotoxic activity (Table 2) against breast cancer (MDA-MB-231 and MCF7), hepatocellular carcinoma (HepG2, Huh7, and HCCLM3), and cervical carcinoma (HeLa) cell lines in a dosedependent manner (Z. Li et al., 2019).

\subsubsection{Nuciferine Safety}

Nuciferine has been found to be a promising anticancer drug. However, its toxicity should not be ignored. Previous experimental studies have shown that the median lethal doses $\left(\mathrm{LD}_{50}\right)$ of nuciferine were $240 \mathrm{mg} / \mathrm{kg}$, po and $280 \mathrm{mg} / \mathrm{kg}$, po in mice and rat, respectively (Bhattacharya et al., 1978; Soleymankhani et al., 2015). Also, another report indicated that nuciferine induced significant hypotension after intravenous injection of $4-10 \mathrm{mg} / \mathrm{kg}$ and $10-20 \mathrm{mg} / \mathrm{kg}$ in cats and dogs, respectively (Neuwinger, 1996).

\subsection{Corydalis yanhusuo W.T. Wang Alkaloids}

Corydalis yanhusuo W.T. Wang (Papaveraceae) is a well-known Chinese herbal plant widely used for various pharmacological properties, especially to improve blood circulation, alleviate pain caused by blood stasis, and reinforce vital energy (J. Zhang et al., 2020b). These biological activities are mainly attributed to their alkaloid constituents (Figure 7) (Tian et al., 2020). In a recent study, alkaloid fractions of Corydalis yanhusuo W.T. Wang demonstrated potent inhibition of a variety of VEGF-induced angiogenic processes such as proliferation, sprouting, migration of endothelial cells, HUVECs, and decreased blood vessel formation in both Matrigel plug of mice and chick chorioallantoic membrane models. Wan et al. (2019) concluded that the mechanism underlying these effects is related to the suppression of the VEGF-induced signaling pathway through VEGFR2 phosphorylation diminution, which 


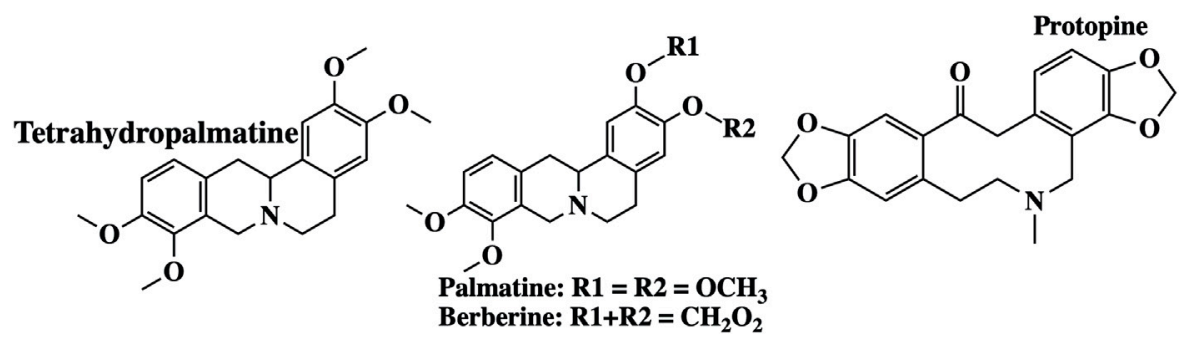

FIGURE 7 | Examples of molecular structures of alkaloids obtained from Corydalis yanhusuo.

leads to downstream phospho-ERK1/2, phospho-AKT, and phospho-STAT3 levels in HUVECs (Wan et al., 2019). In another study, Kośmider et al. (2017) evaluated the cytotoxic effect of the tetracyclic alkaloid-free aqueous extract of Uncaria tomentosa leaf against cancer HepG2 cells. The results from this study show the differential effects of these alkaloids on cancer and normal NHDF cells. It exhibits significant cytotoxic activity in HepG2 cells by activating caspase 3 and caspase 9 compared to that in normal cells. Furthermore, in cancer cells, NF- $\kappa B$ expression is reduced, which may prevent the development of multidrug resistance to chemotherapy (Kośmider et al., 2017).

\section{ANTICANCER PLANT-BASED ALKALOIDS: CLINICAL TRIALS}

\subsection{Methylxanthines}

\subsubsection{Preclinical Studies}

Previous research demonstrated that methylxanthines exhibits antitumor activity in animal models and differential cytotoxic effect against cancer cells such as Caco-2, A549, and T24 (AmigoBenavent et al., 2017). Also, it was reported that methylxanthine derivatives such as theobromine and theophylline effectively suppress MGC-803 gastric cancer cell proliferation and migration, induce apoptosis, and promote autophagy in both in vivo and in vitro through LC-3, Beclin-1/Bax, and Bcl-2/Bcl-xL regulation, PTEN activation, PI3K-Akt-mTOR signaling pathway suppression, blocking cell migration through the ROCK/FAK pathway and may exert its effects on global epigenetic machinery mediated by HAT-histone acetyltransferases, HDAC-2, and HDAC-1, and regulating alternative splicing by targeting SRSF3 (Pérez-Pérez et al., 2019). Furthermore, it has been reported that caffeine, another alkaloid belonging to methylxanthine family (1,3,7-trimethylxanthine), activates p38 MAPK phosphorylation through production of ROS and an increase in the intracellular calcium $\mathrm{Ca}^{2+}$ concentration in U937 cancer cells (Cui et al., 2020). Moreover, Cheng et al. reported that caffeine decreased the invasion of glioma cancer cells via FAK and ERK signaling pathways (Cheng et al., 2016). Also, it exhibits anti-tumor immune response by increasing $\mathrm{T}$ lymphocyte infiltration and decreasing PD-1 expression on $\mathrm{CD}^{+}$ $\mathrm{T}$ lymphocytes and $\mathrm{CD} 4^{+}$and $\mathrm{CD} 25^{+}$regulatory $\mathrm{T}$ lymphocytes in caffein-treated groups in a carcinogen-induced local fibrosarcomas tumor model (Tej et al., 2019). The anti-tumor effect of caffeine observed in this study is mediated through the release of cytokines TNF- $\alpha$ and IFN- $\boldsymbol{\gamma}$. Thus, Tej et al., 2019 suggested that blockade of the adenosine pathway by caffeine can effectively enhance the anti-tumor immune response.

\subsubsection{Clinical Studies}

Ávila-Gálvez and coworkers showed in a randomized clinical trial (NCT03482401) that the disposition of methylxanthines (theobromine and caffeine) in malignant and normal breast tissues after consumption of dietary methylxanthines including theobromine $(19.2 \pm 0.6 \mathrm{mg}$ day -1$)$ and caffeine $(0.48 \pm 0.03 \mathrm{mg}$ day-1) could provide chemoprevention and/or treatment of breast cancer. Numerous mechanistic studies have shown that methylxanthines inhibit polymerase 1 under physiological conditions and reverse multidrug resistance by downregulating the breast cancer resistance protein (ABCG2/BCRP), which may increase the efficacy of anticancer drugs that are the ABCG2/ BCRP substrate (Ávila-Gálvez et al., 2019) (Ávila-Gálvez et al., 2019) (Figure 8).

Similarly, it has been reported previously that methylxanthine blocks the nuclear enzyme poly (ADP-ribose)polymerase1 (Geraets et al., 2006), rendering tumor cells more sensitive to chemotherapeutic drugs (Rosendahl et al., 2015) and reverses breast cancer cell resistance to various conventional drugs by downregulating the breast cancer resistance protein (BCRP/ ABCG2) (Ding et al., 2012).

\subsubsection{Methylxanthine Safety}

Methylxanthine toxicity depends on its alkaloid derivative and the animal in question. In the rate, the LD values were $206 \mathrm{mg} / \mathrm{kg}$, $200 \mathrm{mg} / \mathrm{kg}$, and $950 \mathrm{mg} / \mathrm{kg}$ for theophylline, caffeine, and theobromine, respectively. In human, the $\mathrm{LD}$ values were $1000 \mathrm{mg} / \mathrm{kg}$ for theobromine and $192 \mathrm{mg} / \mathrm{kg}$ for caffeine. Consequently, human acute toxicity regarding methylxanthines is very low. However, it should be kept in mind that methylxanthine pharmacological concentrations of high doses could cause anxiety, an increase in gastric secretion, and heart rate (Bonetti et al., 2017). Furthermore, it is important to note that methylxanthine derivatives may have a negative impact on pregnancy and general offspring development. In zebrafish embryos, theophylline, caffeine, pentoxifylline, 3-isobutyl-1methylxanthine, etophylline, aminophylline, and doxofylline were embryotoxic and teratogenic at higher doses. Ref methylxanthines induce structural and functional alterations of 

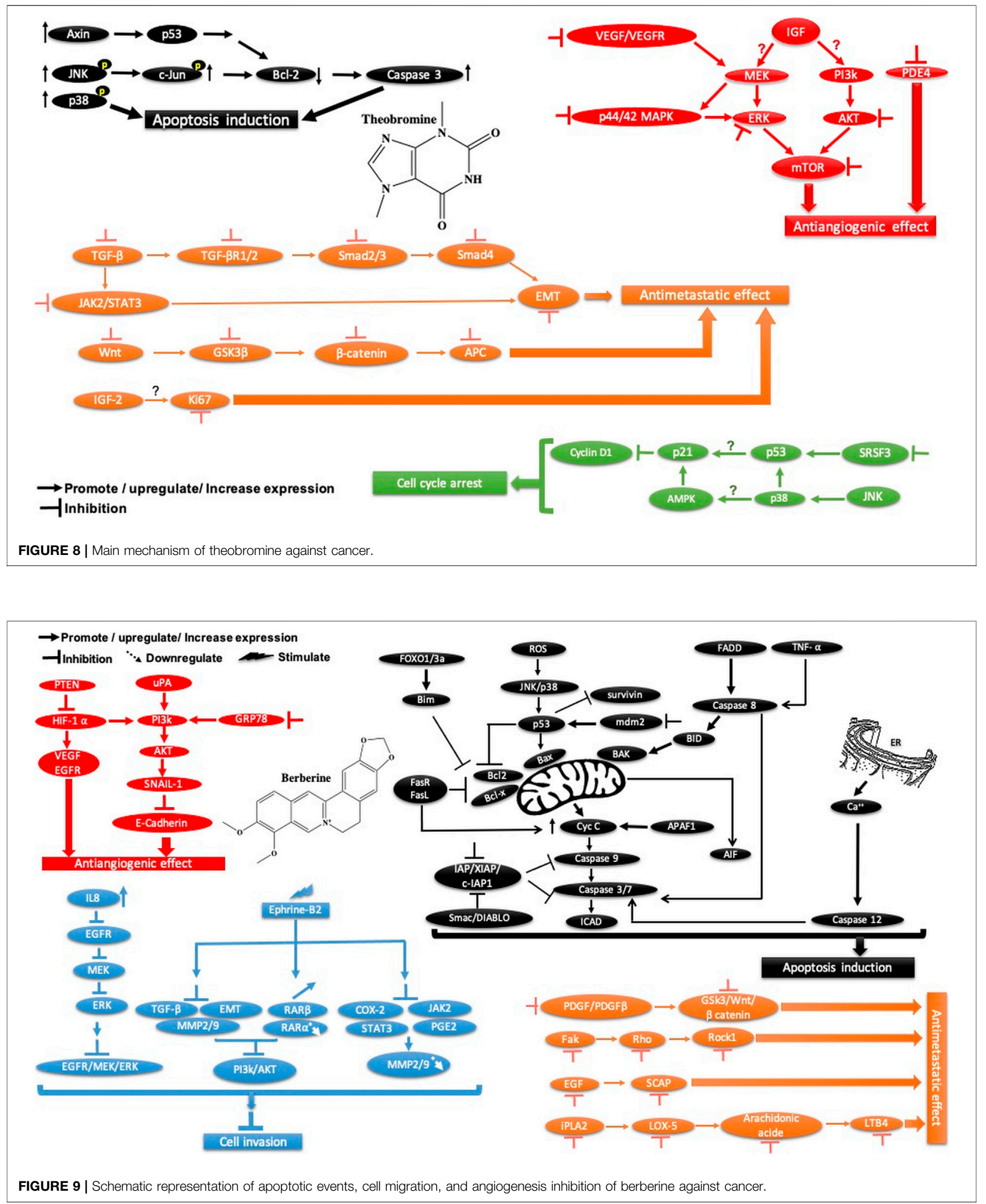


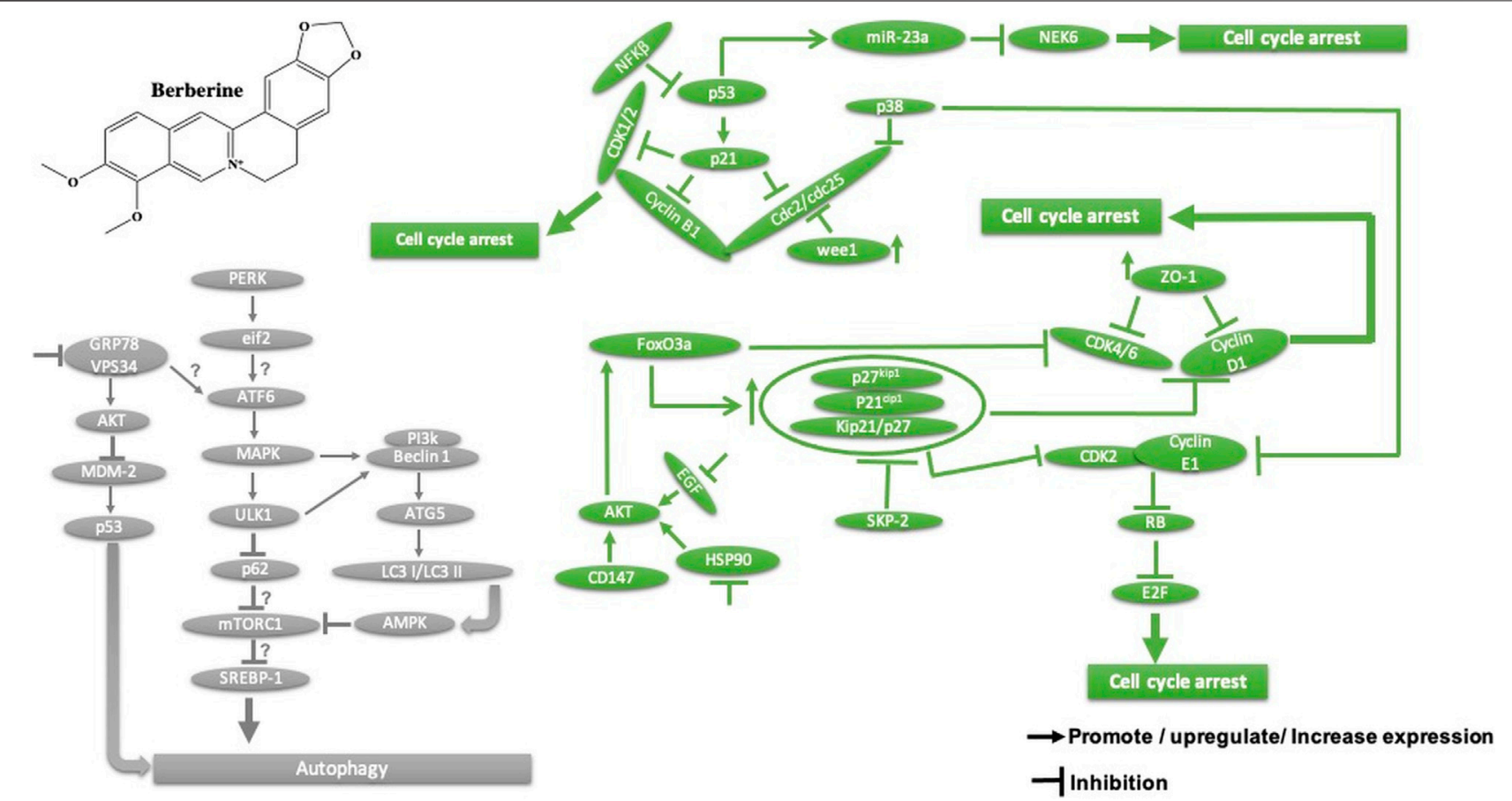

FIGURE 10 | Overview of the main molecular mechanisms of berberine-induced autophagy and cell cycle arrest.

the cardiac system in zebrafish embryos. Early studies showed that caffeine intake slightly increases the risk of spontaneous abortion (Weng et al., 2008), increases the risk of intrauterine growth restriction, increases the incidence of congenital limb deficiencies (Chen et al., 2012), and increases the risk of having a baby with cryptorchidism (if the dose exceeds $400 \mathrm{mg} /$ day) (Mongraw-Chaffin et al., 2008), encephalocele, and spina bifida (Schmidt et al., 2009). However, other epidemiological studies reported negative effects on prenatal and pregnancy outcomes associated to maternal ingestion of high and moderate doses of caffeine (Ådén, 2011).

\subsection{Berberine}

\subsubsection{Preclinical Studies}

Berberine is another plant-derived alkaloid that has been reported to exhibit in vitro and in vivo cancer activities. In our lab, berberine from Berberis vulgaris was found to exhibit strong cytotoxic activity against the breast cancer cell line MCF-7, with an $\mathrm{IC}_{50}=8.75 \mu \mathrm{g} /$ $\mathrm{ml}$. The cytotoxic effect is attributed to its ability to induce apoptosis without pronounced cytotoxic activity in normal cells. In another study, it exhibited antiproliferative activity, decreased the migration and invasion of gastric carcinoma cells, and suppressed gastric carcinoma tumor growth in vivo (Table 2). The anti-gastric carcinoma effect of berberine might be linked to the AMPK/HNF4 a/WNT5A pathway (Hu et al., 2018) (Figure 9). However, Wang and Zhang found that berberine isolated from Rhizoma coptidis inhibits endometrial tumor cell motility, invasion, and metastasis in vitro and in vivo through miR-101COX2-PGE2 signaling pathways (Figure 9) (Y. Wang and Zhang 2018, 2). In addition, berberine mediated suppression of cell motility by downregulating the transforming growth factor $B-1$ in triple-negative breast cancer cells (Kim et al., 2018) and induced apoptosis through activation of caspase 9/cytochrome c, which leads to growth inhibition of TNBC cells in both in vitro and in vivo assays (Figure 9). In liver cancer, berberine inhibits hepatocellular carcinoma Hep3B and BEL-7404 via suppression of glutamine uptake by inhibiting SLC1A5 and c-Myc both in vitro and in vivo (P. Zhang et al., 2019). In a recent study, berberine was found to repress human gastric cell proliferation both in vitro and in vivo by the autophagy process and cell cycle arrest (Figure 10) through blocking cyclins and the Akt and MAPK-mTOR-p70S6K pathways (Q. Zhang et al., 2020c).

\subsubsection{Clinical Studies}

Moreover, berberine $(0.3 \mathrm{~g})$ taken twice daily by oral administration was highly effective against colorectal adenomas, and no colorectal cancers were detected during follow-up. In addition, it was safe, with no serious adverse events. Thus, the authors concluded that berberine could be effectively used to reduce the risk of colorectal adenoma recurrence, polypoid lesions, and as a chemopreventive agent after polypectomy NCT02226185. However, it has been concluded that the mechanism of action of berberine is still unclear (Y.-X. Chen et al., 2020).

\subsubsection{Berberine Safety}

Berberine can play an important role in prevention and treatment of cancer. However, its toxicity should not be dismissed. Overall, berberine has shown very low toxicity in animal studies (Mohammadzadeh, Mehri, and Hosseinzadeh 2017). Its toxicity depends on the animal species, route of administration, and the dose. In rat, the $\mathrm{LD}_{50}$ of berberine is 


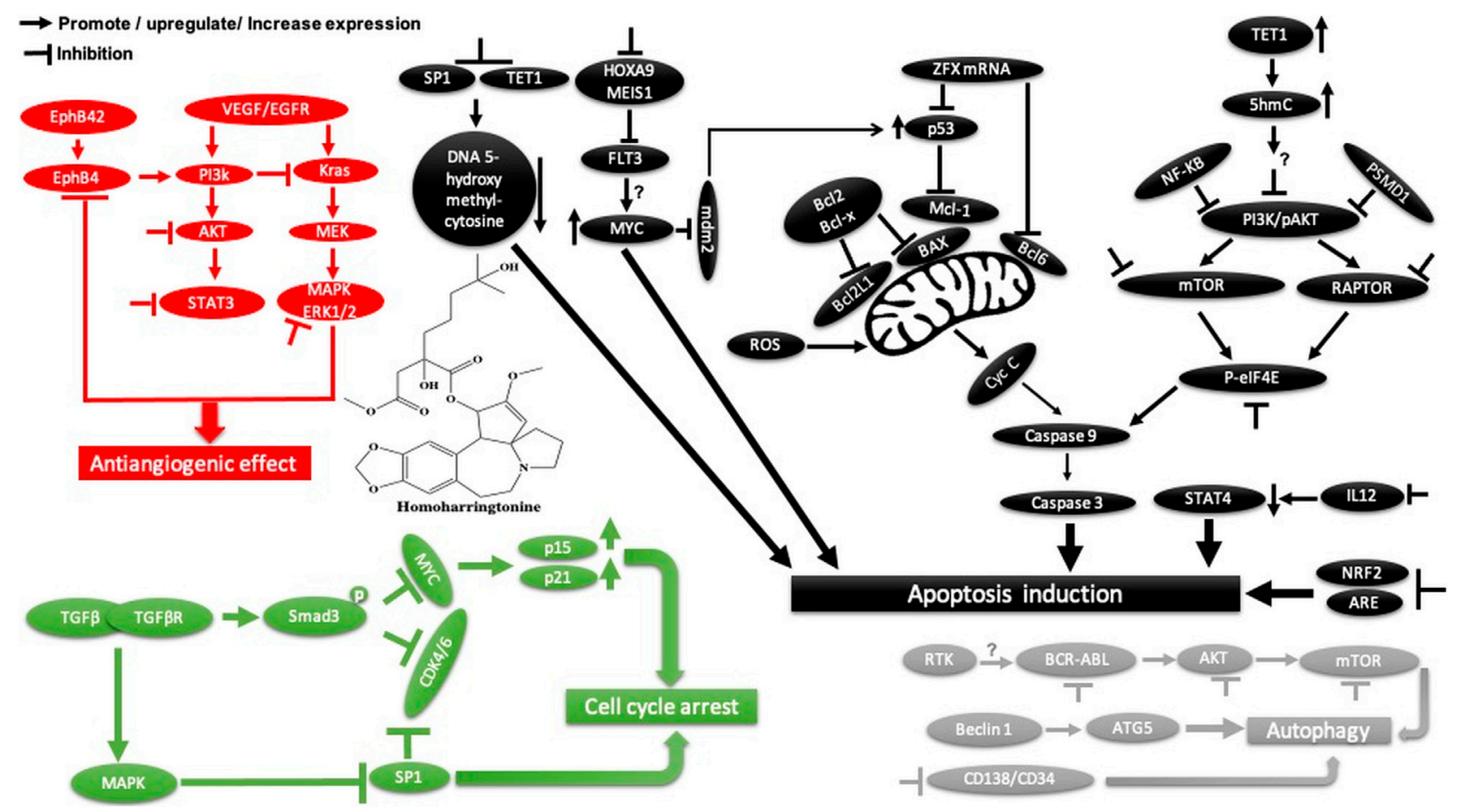

FIGURE 11 | Main mechanism of homoharringtonine against cancer in inducing apoptosis, autophagy, cell cycle arrest, and angiogenesis inhibition.

$>15,000 \mathrm{mg} / \mathrm{kg}$, and the $\mathrm{LD}_{50}$ values in mice are $20.8 \mathrm{~g} / \mathrm{kg}$, $57.6 \mathrm{mg} / \mathrm{kg}$, and $9.03 \mathrm{mg} / \mathrm{kg}$ through oral, intraperitoneal, and intravenous administration, respectively (Kheir et al., 2010). In human, the dose used to treat metabolic disease ranged from 0.4 to $1.5 \mathrm{~g}$ /day (Xu et al., 2021). Some clinical trials have reported mild gastrointestinal adverse reactions, including constipation and diarrhea (Imenshahidi and Hosseinzadeh 2019), and no adverse effects have been seen in the liver (Xu et al., 2021). In high doses, berberine has been associated with dyspnea, flu-like symptoms, cardiac damage, and hypotension (Imanshahidi and Hosseinzadeh, 2008; Imenshahidi and Hosseinzadeh, 2016). Other studies showed that berberine may lead to kernicterus in infants with glucose-6-phosphate dehydrogenase deficiency (Fung and Linn, 2015). Also, berberine can act directly on the fetus development, and it may lead to birth abnormalities. Thus, its use during pregnancy, neonatal, and breastfeeding is cautioned. Conversely, berberine has not been found to cause cytotoxicity, mutagenicity, and genotoxicity with its prescribed clinical doses (Rad et al., 2017). Further preclinical studies on berberine safety on animals and well-designed human clinical trials could better delineate and understand the therapeutic role of berberine in humans.

\subsection{Homoharringtonine}

\subsubsection{Preclinical Studies}

Homoharringtonine, another natural plant alkaloid isolated from Cephalotaxus species, has been used widely for more than 30 years in traditional Chinese medicine for the treatment of hematologic malignancies, most notably acute myeloid leukemia (AML) (Table 2). It is well known that homoharringtonine potently inhibits cell growth and viability and induces cell cycle arrest and apoptosis (Figure 11), significantly inhibits disease progression in vivo, and substantially prolongs the survival of mice bearing murine or human AML. Interestingly, homoharringtonine treatment dramatically decreased global DNA 5-hydroxymethylcytosine abundance by targeting the SP1/ TET1 axis, and TET1 depletion mimics the therapeutic effects of homoharringtonine in AML (Figure 11). Another relevant molecular mechanism explaining its potent therapeutic activity in AML involves the suppression of the SP1/TET1/5hmC/FLT3HOXA9-MEIS1/MYC signaling pathway (C. Li et al., 2020a). Another mechanism by which homoharringtonine inhibits the activity of Sca1-positive c-kit-negative Lin-negative leukemia stem cells in murine leukemia and causes a downregulation of the c-myc signaling pathway in Kasumi-1 human leukemia cells is by directly binding to the NF-kB repressor factor. Thus, expressed genes, especially kit and c-myc, could be used as biomarkers in patients with AML under homoharringtonine treatment (X.-J. Chen et al., 2019a). Similarly, the developed polyethyleneglycol of longcirculating homoharringtonine liposomes has been shown to suppress CD138-CD34- (Figure 11) multiple myeloma cancer stem cells via autophagy and apoptosis in vitro and in vivo in a xenograft mouse model (M. Li et al., 2017). Recent studies have revealed the antitumor effect of homoharringtonine against rhabdoid tumors both in vitro and in patient-derived xenograft tumors, which may be due to the low expression of BCL2L1 in cancer cell lines (Howard et al., 2020). 


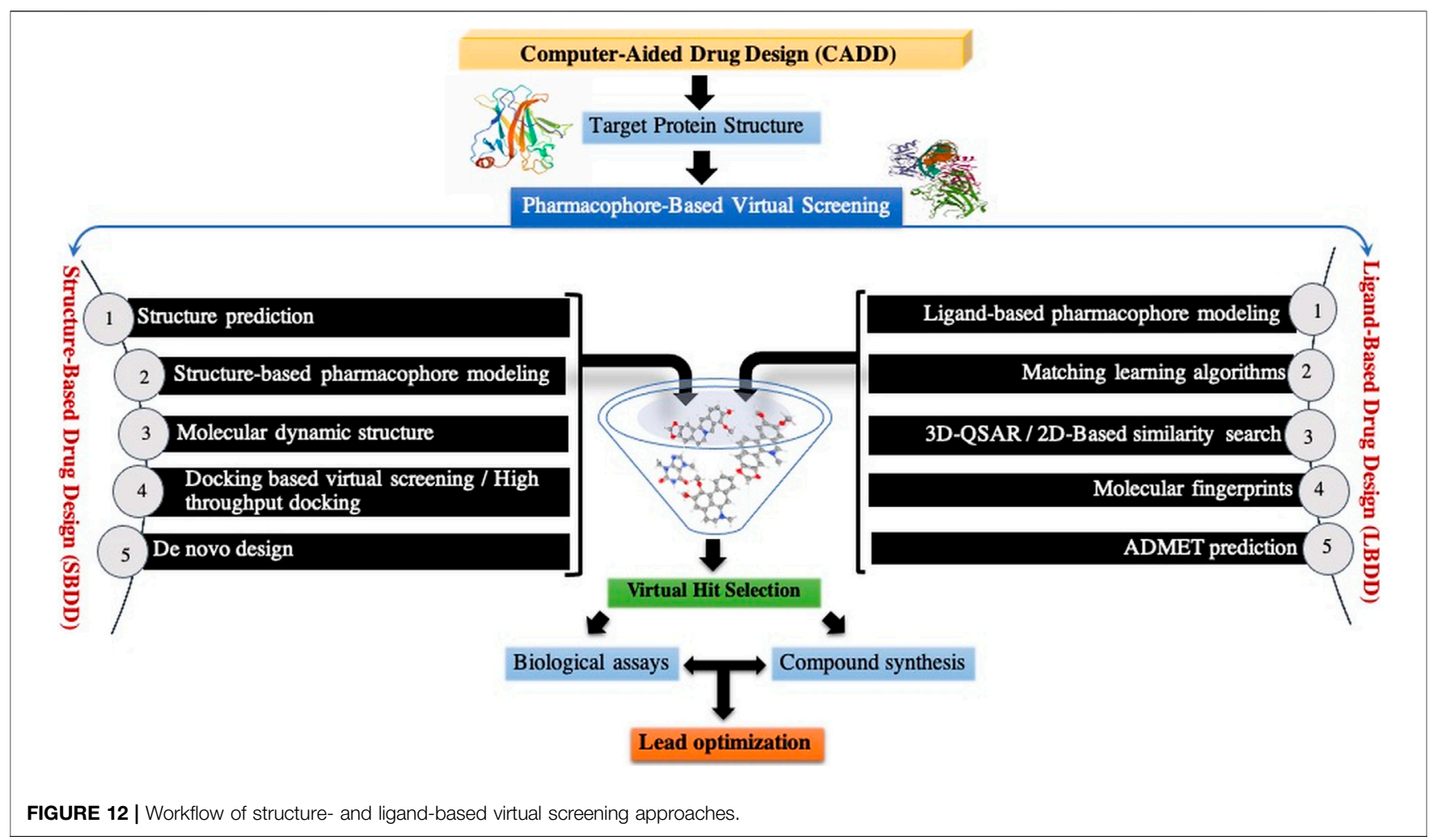

Homoharringtonine has also been reported to have cancer properties against breast cancer. It demonstrates strong cytotoxic activity against triple-negative breast cancer cell lines (MDA-MB231) in a dose- and time-dependent manner. It has also been shown to reduce tumor growth in a mouse model at $1 \mathrm{mg} / \mathrm{kg}$ administered subcutaneously twice daily over 7 days (Yakhni et al., 2019). In chronic myelogenous leukemia (K562), homoharringtonine increases the activity of imatinib by downregulating ZFX mRNA, blocking the bcl-6/p53 pathway, and inducing apoptosis (Q. Wang et al., 2017b). In addition to the apoptotic pathway, homoharringtonine has been demonstrated to induce autophagy in imatinib-resistant $\mathrm{K} 562 \mathrm{G}$ cells through degradation of the BCR-ABL protein mediated by p62 and silencing of the main autophagic proteins Beclin-1 and ATG5 (Figure 11) (S. Li et al., 2020b).

Another study showed that homoharringtonine significantly inhibited the NRF2- and ARE-dependent gene expression in human lung carcinoma cell lines (A549) with an $\mathrm{IC}_{50}=$ $12.28 \mathrm{nM}$ by stabilizing the secondary structure of the guanine-rich enhancer sequence within the $5^{\prime}$ untranslated region ( $\left.5^{\prime} \mathrm{UTR}\right)$ and sensitizes A549 tumor cells to etoposideinduced apoptosis. It is well known that etoposide sensitization triggers apoptosis by increasing the intracellular reactive oxygen species level ref 15 , which may explain the cytotoxic effect of homoharringtonine toward A549 cells (Kang et al., 2019, 2).

Based on further mechanistic studies, it can be concluded that homoharringtonine induces inhibition of LoVo cell growth in vitro and in vivo through apoptosis, cell cycle arrest at the $\mathrm{S}$ phase, and the inhibition of the signaling pathways including MAPK-ERK1/2,PI3K-AKT and EphB4 (Shi et al., 2020). Another study has shown that homoharringtonine significantly inhibits the growth and proliferation of pancreatic cancer cells (PANC-1, MiaPaCa), induces apoptosis and activates MEK1-ERK1/2, leading to rapid expression of PSMD11, which could explain its reported cytotoxic effects (Figure 11) (L. Wang et al., 2018). Moreover, homoharringtonine induced changes in immune cell features by decreasing the expression level of IL12 and the overexpression of CD80, CD86, CD69, CD80 ${ }^{+}$, and CD86 in B220 + B cells and B cells, respectively, in non-small cell lung cancer. These immunological effects were linked to the cytotoxic and anti-tumor activities of homoharringtonine via Krasmutant gene (G12D, G12C) expression in non-small cell lung adenocarcinoma (Weng et al., 2018). It causes alternative splicing of caspase 9 and $\mathrm{Bcl}-\mathrm{x}$ with increasing pro-apoptotic $\mathrm{Bcl}-\mathrm{xS}$ and caspase $9 \mathrm{~b}$ mediated by the expression of protein phosphatase 1, leading to apoptosis in various human cancer cell lines (MCF7, A549, UACC903) (Sun Q. et al., 2018).

Another mechanism of homoharringtonine in the treatment of AML is the targeting of phospho-eIF4E. Research has shown that homoharringtonine selectively reduced p-eIF4E with a decrease in McL-1 oncoprotein expression in vitro and in vivo as well (Zhou et al., 2020). In HT29, it induces apoptosis by suppressing $\mathrm{mTOR}$ and increasing the ratio of $\mathrm{BAX} / \mathrm{Bcl} 2$, caspase 3.9, and raptor, while PI3k, AKT, and the receptor pathway were decreased. Another mechanism involved smad3 phosphorylation (Ser423/4235) to consequently affect TGF- $\beta$ pathway activation, 
promoting cell cycle arrest at the G1 phase in AML cell lines U937 and kG-1 (J. Chen et al., 2017).

\subsubsection{Clinical Studies}

Based on previous intense preclinical research and clinical trials, homoharringtonine has been approved by the US Food and Drug Administration (FDA) for the treatment of patients with chronic myeloid lymphoma and chronic myeloid leukemia resistance to imatinib and/or other tyrosine kinase inhibitors (Q. Wang et al., 2017b). Recently, it has been reported to be effective in patients with myelodysplastic syndrome in clinical phase II (Daver et al., 2013). Furthermore, its effect on bone marrow CD34 + CD117+ cells has been investigated in patients with chronic myelogenous leukemia (Y.-F. Li et al., 2012). Another phase II clinical study showed that homoharringtonine at $5 \mathrm{mg} / \mathrm{m}^{2}$ administered daily for 9 days by continuous infusion was found to be effective and safe for patients with relapsed or refractory acute leukemia and the blastic phase of chronic myelogenous leukemia (E. Feldman et al., 1992). However, under some circumstances, its efficacy is limited to marrow hypoplasia and prolonged pancytopenia in patients with myelodysplastic syndromes evolving to acute myeloid leukemia, compared to when it is administered in combination with hematopoietic growth factors (E. J. Feldman et al., 1996). It is noteworthy that homoharringtonine was approved by the Food and Drug Administration for the treatment of patients with chronic myeloid leukemia (Q. Wang et al., 2017b). Recently, Chen X. et al. (2019), in a randomized clinical trial, it was concluded that homoharringtonine was more efficient in the treatment of children younger than 2 years with de novo acute myeloid leukemia than standard regimen chemotherapy using anthracyclines. Importantly, homoharringtonine has been shown to reduce hematologic toxicity and achieve excellent event-free survival (X. Chen X.-J. et al., 2019).

\subsubsection{Homoharringtonine Safety}

Homoharringtonine's major toxicity is limited to the gastrointestinal tract, cardiovascular system, hematopoietic organs, and lymphoid system in rabbits, mice, and dogs (Yongji et al., 1979; Newman, Meeks, and Denine 1981). The $\mathrm{LD}_{50}$ of homoharringtonine of CD-1 mice was $6.7 \mathrm{mg} / \mathrm{kg}$ for a single i. p. injection. However, its primary metabolite homoharringtonine acid does not appear to be toxic at doses high to $280 \mathrm{mg} / \mathrm{kg}$. In humans, the therapeutically effective and maximum tolerated dose was $4 \mathrm{mg} / \mathrm{day}$ for acute lymphoblastic leukemia. Clinical trials regarding the toxic effects of homoharringtonine are mainly stomatitis, nausea, myelosuppression, emesis, and disturbances in cardiovascular function (Legha et al., 1984; Kantarjian et al., 2001; Ni et al., 2003). In addition, the relative efficacy and toxicity of the homoharringtonine drug may also be influenced in patients with hepatic failure. In the case of pediatric patients, homoharringtonine is well tolerated. Nevertheless, some studies have indicated that homoharringtonine use is associated with mucositis, nausea, vomiting, diarrhea, transient changes of hepatic enzymes, and hypotension (at a dose $=7 \mathrm{mg}$ / $\mathrm{m}^{2}$ per day for up to 10 days) (Coonley et al., 1983; Neidhart et al., 1986; Luo et al., 2004).

\section{CONCLUSION AND FUTURE PERSPECTIVES}

Cancer is the leading cause of death and a major public health concern worldwide, and its burden is expected to rise in 2040, with 28.4 million cases (Sung et al., 2021). To avoid the serious side effects associated with traditional therapies, natural compounds, especially those isolated from plants, have been widely used in cancer prevention and/or treatment. Alkaloids isolated from plants are important chemical compounds that serve as rich reservoirs of bioactive candidate molecules for anticancer drug discovery, and many FDA-approved alkaloids currently in the market are derived from plants. In the last 5 years, some of them have shown various degrees of success in different clinical trial phases. Taken together, palmatine, sophoridine, and aleutianamine have great potential as candidate drugs that require further in vitro and in vivo investigations for treating colon, lung, and pancreatic cancers, respectively, to pave the way for clinical studies. Furthermore, both preclinical research and clinical trials establish that berberine and homoharringtonine are a promising drug against colorectal or breast and acute myeloid leukemia or breast cancers, respectively.

Several plant-based alkaloids exhibit anticancer activities at micromolar or nanomolar concentrations (Table 2), and their mechanisms of action are very complex and vary among different alkaloids. Taken together, the anticancer activity of these alkaloids against various cancer cell lines affects cell growth, cell cycle, cell invasion, angiogenesis, metastasis, autophagy, and apoptosis. Although many plant-based alkaloids demonstrate anticancer properties, the underlying molecular mechanism remains unclear, mainly the interaction between the alkaloid-binding site and the target protein.

The combination of high-throughput bioinformatics-based data mining techniques and molecular assays has significantly improved our understanding of the molecular pathogenesis of cancer, classification of tumors, and now the management of cancer patients in the clinic. There are a number of bioinformatics-based approaches for mining data derived from high-throughput information-rich methods such as genomic, microarray gene (gene chip) epigenetic, genome architecture, cistromic, transcriptomic, proteomic, and ribosome profiling data have all made significant contribution for identification of molecular targets in cancer and elucidation of molecular pathways. For example, weighted gene co-expression network analysis (WGCNA) can be used with network pharmacology to predict and decipher the molecular mechanism of alkaloids in the treatment of cancer (Yuan et al., 2020). Nowadays, computer-aided drug discovery and design (CADDD) computation tools are used for management, modeling, and analysis of molecules (Song, Lim, and Tong 2009) at every phase of cancer-drug discovery project, from lead optimization and target validation to preclinical research (Jorgensen 2004) (Figure 12). 
Structure-based pharmacophore modeling and computational approaches such as quantitative structure-activity relationships (QSAR) and quantitative structure-properties relationships (QSPR) may provide useful insights into the nature of ligandbinding sites in the different targets and identifying new interaction points and novel ligands with efficient ligand-receptor binding affinity, which in consequence results in predictive models that can be adequate for drug hit discovery and applied in virtual screening, multitarget drug design, lead discovery, optimization, and in the de novo design (Prada-Gracia et al., 2016) (Figure 11). One of the most widely applied groups of docking algorithms used in the de novo drug design is genetic algorithms used by docking software such as AutoDock (Tiwari et al., 2009), GOLD (Maia et al., 2020), GANDI (Dey and Caflisch, 2008), and PhDD (pharmacophorebased de novo design) (Huang et al., 2010).

Plant-derived alkaloids have historically been continuing and will continue to be a precious source for both cytotoxic

\section{REFERENCES}

Ådén, U. (2011). Methylxanthines during Pregnancy and Early Postnatal Life. Methylxanthines 1, 373-389.

Amigo-Benavent, M., Wang, S., Mateos, R., Sarriá, B., and Bravo, L. (2017). Antiproliferative and Cytotoxic Effects of Green Coffee and Yerba Mate Extracts, Their Main Hydroxycinnamic Acids, Methylxanthine and Metabolites in Different Human Cell Lines. Food Chem. Toxicol. 106, 125-138. doi:10.1016/j.fct.2017.05.019

Ávila-Gálvez, M., Ángeles, M., García-Villalba, R., Martínez-Díaz, F., OcañaCastillo, B., Monedero-Saiz, T., et al. (2019). Metabolic Profiling of Dietary Polyphenols and Methylxanthines in Normal and Malignant Mammary Tissues from Breast Cancer Patients. Mol. Nutr. Food Res. 63 (9), 1801239.

Berdigaliyev, N., and Aljofan, M. (2020). An Overview of Drug Discovery and Development. Future Med. Chem. 12 (10), 939-947. doi:10.4155/fmc-20190307

Beklen, H., Arslan, S., Gulfidan, G., Turanli, B., Ozbek, P., Karademir Yilmaz, B., et al. (2021). Differential Interactome Based Drug Repositioning Unraveled Abacavir, Exemestane, Nortriptyline Hydrochloride, and Tolcapone as Potential Therapeutics for Colorectal Cancers. Front. Bioinforma. 1. doi:10.3389/fbinf.2021.710591

Bhattacharya, S. K., Bose, R., Ghosh, P., Tripathi, V. J., Ray, A. B., and Dasgupta, B. (1978). Psychopharmacological Studies on (--)-nuciferine and its Hofmann Degradation Product Atherosperminine. Psychopharmacology (Berl) 59 (1), 29-33. doi:10.1007/BF00428026

Boik, J. (2001). Natural Compounds in Cancer Therapy. Vol. 851. Princeton, MN: Oregon Medical Press.

Bonetti, F., Brombo, G., and Zuliani, G. (2017). "Nootropics, Functional Foods, and Dietary Patterns for Prevention of Cognitive Decline," in Nutrition and Functional Foods for Healthy Aging (Elsevier), 211-232. doi:10.1016/b978-012-805376-8.00019-8

Bouquet, J., Rivaud, M., Chevalley, S., Deharo, E., Jullian, V., and Valentin, A. (2012). Biological Activities of Nitidine, a Potential Anti-malarial Lead Compound. Malar. J. 11 (1), 67-68. doi:10.1186/1475-2875-11-67

Caraglia, M., Marra, M., Giuberti, G., D’Alessandro, A. M., Beninati, S., Lentini, A., et al. (2002). Theophylline-Induced Apoptosis Is Paralleled by Protein Kinase A-dependent Tissue Transglutaminase Activation in Cancer Cells. J. Biochem. 132 (1), 45-52. doi:10.1093/ oxfordjournals.jbchem.a003197

Chakravarthy, D., Muñoz, A. R., Su, A., Hwang, R. F., Keppler, B. R., Chan, D. E., et al. (2018). Palmatine Suppresses Glutamine-Mediated Interaction between Pancreatic Cancer and Stellate Cells through Simultaneous Inhibition of Survivin and COL1A1. Cancer Lett. 419, 103-115. doi:10.1016/ j.canlet.2018.01.057 chemotherapy and molecular-targeted cancer therapy. Sometimes, but more often, they need careful structural optimization to improve their efficacy, pharmacokinetic, and safety profiles as well as chemical accessibility. Furthermore, a deep understanding of the cross-talk between alkaloids and associated signaling pathways will be helpful to better understand their molecular mechanisms of action and pharmacokinetic performances and therefore the development of anticancer drugs that are more effective, selective, and less toxic.

\section{AUTHOR CONTRIBUTIONS}

MT wrote and designed the manuscript. AZ and HAM revised the manuscript. All authors have made a substantial and intellectual contribution to the content of the manuscript and approved it for publication.

Chen, J., Mu, Q., Li, X., Yin, X., Yu, M., Jin, J., et al. (2017). Homoharringtonine Targets Smad3 and TGF- $\beta$ Pathway to Inhibit the Proliferation of Acute Myeloid Leukemia Cells. Oncotarget 8 (25), 40318-40326. doi:10.18632/ oncotarget.16956

Chen, L., Bell, E. M., Browne, M. L., Druschel, C. M., Romitti, P. A., Schmidt, R. J., et al. (2012). Maternal Caffeine Consumption and Risk of Congenital Limb Deficiencies. Birth Defects Res. A. Clin. Mol. Teratol 94 (12), 1033-1043. doi:10.1002/bdra.23050

Chen, X., Tang, Y., Chen, J., Chen, R., Gu, L., Xue, H., et al. (2019a). Homoharringtonine Is a Safe and Effective Substitute for Anthracyclines in Children Younger Than 2 Years Old with Acute Myeloid Leukemia. Front. Med. 13 (3), 378-387. doi:10.1007/s11684-018-0658-4

Chen, X.-J., Zhang, W.-N., Chen, B., Xi, W.-D., Lu, Y., Huang, J.-Y., et al. (2019b). Homoharringtonine deregulatesMYCtranscriptional Expression by Directly Binding NF-Kb Repressing Factor. Proc. Natl. Acad. Sci. USA 116 (6), 2220-2225. doi:10.1073/pnas.1818539116

Chen, Y.-X., Gao, Q.-Y., Zou, T.-H., Wang, B.-M., Liu, S.-D., Sheng, J.-Q., et al. (2020). Berberine versus Placebo for the Prevention of Recurrence of Colorectal Adenoma: A Multicentre, Double-Blinded, Randomised Controlled Study. Lancet Gastroenterol. Hepatol. 5 (3), 267-275. doi:10.1016/s2468-1253(19) 30409-1

Cheng, Y. C., Ding, Y. M., Hueng, D. Y., Chen, J. Y., and Chen, Y. (2016). Caffeine Suppresses the Progression of Human Glioblastoma via Cathepsin B and MAPK Signaling Pathway. J. Nutr. Biochem. 33, 63-72. doi:10.1016/ j.jnutbio.2016.03.004

Choudhari, A. S., Mandave, P. C., Deshpande, M., Ranjekar, P., and Prakash, O. (2020). Phytochemicals in Cancer Treatment: From Preclinical Studies to Clinical Practice. Front. Pharmacol. 10. doi:10.3389/fphar.2019.01614

Coonley, C. J., Warrell, R. P., Jr, and Young., C. W. (1983). Phase I Trial of Homoharringtonine Administered as a 5-Day Continuous Infusion. Cancer Treat. Rep. 67 (7-8), 693-696.

Cui, W. Q., Wang, S. T., Pan, D., Chang, B., and Sang, L. X. (2020). Caffeine and its Main Targets of Colorectal Cancer. World J. Gastrointest. Oncol. 12 (2), 149-172. doi:10.4251/wjgo.v12.i2.149

Daver, N., Vega-Ruiz, A., Kantarjian, H. M., Estrov, Z., Ferrajoli, A., Kornblau, S., et al. (2013). A Phase II Open-Label Study of the Intravenous Administration of Homoharringtonine in the Treatment of Myelodysplastic Syndrome. Eur. J. Cancer Care (Engl) 22 (5), 605-611. doi:10.1111/ecc.12065

Debnath, B., Singh, W. S., Das, M., Goswami, S., Singh, M. K., Maiti, D., et al. (2018). Role of Plant Alkaloids on Human Health: A Review of Biological Activities. Mater. Today Chem. 9, 56-72. doi:10.1016/j.mtchem.2018.05.001

Dey, F., and Caflisch, A. (2008). Fragment-Based De Novo Ligand Design by Multiobjective Evolutionary Optimization. J. Chem. Inf. Model. 48 (3), 679-690. doi:10.1021/ci700424b

Dey, P., Kundu, A., Kumar, A., Gupta, M., Lee, B. M., Bhakta, T., et al. (2020). "Analysis of Alkaloids (Indole Alkaloids, Isoquinoline Alkaloids, Tropane 
Alkaloids)," in Recent Advances in Natural Products Analysis (Elsevier), 505-567. doi:10.1016/b978-0-12-816455-6.00015-9

Ding, R., Shi, J., Pabon, K., and Scotto, K. W. (2012). Xanthines Down-Regulate the Drug Transporter ABCG2 and Reverse Multidrug Resistance. Mol. Pharmacol. 81 (3), 328-337. doi:10.1124/mol.111.075556

Feldman, E., Arlin, Z., Ahmed, T., Mittelman, A., Puccio, C., Chun, H., et al. (1992). Homoharringtonine Is Safe and Effective for Patients with Acute Myelogenous Leukemia. Leukemia 6 (11), 1185-1188.

Feldman, E. J., Seiter, K. P., Ahmed, T., Baskind, P., and Arlin, Z. A. (1996). Homoharringtonine in Patients with Myelodysplastic Syndrome (MDS) and MDS Evolving to Acute Myeloid Leukemia. Leukemia 10 (1), 40-42.

Fung, F. Y., and Linn, Y. C. (2015). Developing Traditional Chinese Medicine in the Era of Evidence-Based Medicine: Current Evidences and Challenges. Evid. Based Complement. Alternat. Med., 425037. doi:10.1155/2015/425037

Geraets, L., Moonen, H. J., Wouters, E. F., Bast, A., and Hageman, G. J. (2006). Caffeine Metabolites Are Inhibitors of the Nuclear Enzyme poly(ADP-Ribose) polymerase-1 at Physiological Concentrations. Biochem. Pharmacol. 72 (7), 902-910. doi:10.1016/j.bcp.2006.06.023

Hambright, H. G., Batth, I. S., Xie, J., Ghosh, R., and Kumar, A. P. (2015). Palmatine Inhibits Growth and Invasion in Prostate Cancer Cell: Potential Role for rpS6/NFkB/FLIP. Mol. Carcinog 54 (10), 1227-1234. doi:10.1002/ mc. 22192

Hashemi-Niasari, F., Rabbani-Chadegani, A., Razmi, M., and Fallah, S. (2018). Synergy of Theophylline Reduces Necrotic Effect of Berberine, Induces Cell Cycle Arrest and PARP, HMGB1, Bcl-2 Family Mediated Apoptosis in MDAMB-231 Breast Cancer Cells. Biomed. Pharmacother. 106, 858-867. doi:10.1016/j.biopha.2018.07.019

Hematpoor, A., Paydar, M., Liew, S. Y., Sivasothy, Y., Mohebali, N., Looi, C. Y., et al. (2018). Phenylpropanoids Isolated from Piper Sarmentosum Roxb. Induce Apoptosis in Breast Cancer Cells through Reactive Oxygen Species and Mitochondrial-dependent Pathways. Chem. Biol. Interact 279, 210-218. doi:10.1016/j.cbi.2017.11.014

Howard, T. P., Oberlick, E. M., Rees, M. G., Arnoff, T. E., Pham, M. T., Brenan, L., et al. (2020). Rhabdoid Tumors Are Sensitive to the Protein-Translation Inhibitor Homoharringtonine. Clin. Cancer Res. 26 (18), 4995-5006. doi:10.1158/1078-0432.CCR-19-2717

Hu, Q., Li, L., Zou, X., Xu, L., and Yi, P. (2018). Berberine Attenuated Proliferation, Invasion and Migration by Targeting the AMPK/HNF4a/WNT5A Pathway in Gastric Carcinoma. Front. Pharmacol. 9, 1150. doi:10.3389/fphar.2018.01150

Huang, M., Gao, H., Chen, Y., Zhu, H., Cai, Y., Zhang, X., et al. (2007). Chimmitecan, a Novel 9-Substituted Camptothecin, with Improved Anticancer Pharmacologic Profiles In Vitro and In Vivo. Clin. Cancer Res. 13 (4), 1298-1307. doi:10.1158/1078-0432.CCR-06-1277

Huang, Q., Li, L. L., and Yang, S. Y. (2010). PhDD: A New Pharmacophore-Based De Novo Design Method of Drug-like Molecules Combined with Assessment of Synthetic Accessibility. J. Mol. Graph Model. 28 (8), 775-787. doi:10.1016/ j.jmgm.2010.02.002

Imanshahidi, M., and Hosseinzadeh, H. (2008). Pharmacological and Therapeutic Effects of Berberis Vulgaris and its Active Constituent, Berberine. Phytother Res. 22 (8), 999-1012. doi:10.1002/ptr.2399

Imenshahidi, M., and Hosseinzadeh, H. (2019). Berberine and Barberry (Berberis Vulgaris): A Clinical Review. Phytother Res. 33 (3), 504-523. doi:10.1002/ ptr.6252

Imenshahidi, M., and Hosseinzadeh, H. (2016). Berberis Vulgaris and Berberine: An Update Review. Phytother Res. 30 (11), 1745-1764. doi:10.1002/ptr.5693

Jin, F., Xie, T., Huang, X., and Zhao, X. (2018). Berberine Inhibits Angiogenesis in Glioblastoma Xenografts by Targeting the VEGFR2/ERK Pathway. Pharm. Biol. 56 (1), 665-671. doi:10.1080/13880209.2018.1548627

Johnson-Ajinwo, O. R., Richardson, A., and Li, W. W. (2019). Palmatine from Unexplored Rutidea Parviflora Showed Cytotoxicity and Induction of Apoptosis in Human Ovarian Cancer Cells. Toxins (Basel) 11 (4), 237. doi:10.3390/toxins 11040237

Jorgensen, W. L. (2004). The Many Roles of Computation in Drug Discovery. Science 303 (5665), 1813-1818. doi:10.1126/science.1096361

Kang, E. J., Sun, K. L., Park, K.-K., Hwa Son, S., Kim, K. R., and Chung, W.-Y. (2017). Liensinine and Nuciferine, Bioactive Components of Nelumbo Nucifera, Inhibit the Growth of Breast Cancer Cells and Breast Cancer-
Associated Bone Loss. Evid. Based Complement. Alternat. Med., 1583185. doi: $10.1155 / 2017 / 1583185$

Kang, J. S., Lee, J., Nam, L. B., Yoo, O. K., Pham, K. T., Duong, T. H., et al. (2019). Homoharringtonine Stabilizes Secondary Structure of Guanine-Rich Sequence Existing in the 5'-untranslated Region of Nrf2. Bioorg. Med. Chem. Lett. 29 (16), 2189-2196. doi:10.1016/j.bmcl.2019.06.049

Kantarjian, H. M., Talpaz, M., Santini, V., Murgo, A., Cheson, B., O'Brien, S. M., et al. (2001). Homoharringtonine: History, Current Research, and Future Direction. Cancer 92 (6), 1591-1605. doi:10.1002/1097-0142(20010915)92: 6<1591:aid-cncr1485>3.0.co;2-u

Karnam, K. C., Ellutla, M., Bodduluru, L. N., Kasala, E. R., Uppulapu, S. K., Kalyankumarraju, M., et al. (2017). Preventive Effect of Berberine against DMBA-Induced Breast Cancer in Female Sprague Dawley Rats. Biomed. Pharmacother. 92, 207-214. doi:10.1016/j.biopha.2017.05.069

Khan, H., Belwal, T., Efferth, T., Farooqi, A. A., Sanches-Silva, A., Vacca, R. A., et al. (2020). Targeting Epigenetics in Cancer: Therapeutic Potential of Flavonoids. Crit. Rev. Food Sci. Nutr. 1-24, 1-24. doi:10.1080/10408398.2020.1763910

Kheir, M. M., Wang, Y., Hua, L., Hu, J., Li, L., Lei, F., et al. (2010). Acute Toxicity of Berberine and its Correlation with the Blood Concentration in Mice. Food Chem. Toxicol. 48 (4), 1105-1110. doi:10.1016/j.fct.2010.01.033

Kim, L. H., Khadka, S., Shin, J. A., Jung, J. Y., Ryu, M. H., Yu, H. J., et al. (2017). Nitidine Chloride Acts as an Apoptosis Inducer in Human Oral Cancer Cells and a Nude Mouse Xenograft Model via Inhibition of STAT3. Oncotarget 8 (53), 91306-91315. doi:10.18632/oncotarget.20444

Kim, S., Lee, J., You, D., Jeong, Y., Jeon, M., Yu, J., et al. (2018). Berberine Suppresses Cell Motility through Downregulation of TGF-B1 in Triple Negative Breast Cancer Cells. Cell Physiol Biochem 45 (2), 795-807. doi:10.1159/ 000487171

Kośmider, A., Czepielewska, E., Kuraś, M. L., Gulewicz, K., Pietrzak, W., Nowak, R., et al. (2017). Uncaria Tomentosa Leaves Decoction Modulates Differently ROS Production in Cancer and Normal Cells, and Effects Cisplatin Cytotoxicity. Molecules 22 (4), 620.

Kuete, V., and Efferth, T. (2015). African Flora Has the Potential to Fight Multidrug Resistance of Cancer. Biomed. Res. Int. 2015, 1. doi:10.1155/2015/ 914813

Kuete, V., Blanche, L., Nguekeu, Y. M. M., Çelik, I., Mbouangouere, R., Karaosmanoğlu, O., et al. (2018). Ardisinol III, a Naturally Occurring Alkenylmethylresorcinol Displayed Cytotoxic Effects in Carcinoma Cells. Invest. Med. Chem. Pharmacol. 1, 1-6. doi:10.31183/imcp.2018.00014

Legha, S. S., Keating, M., Picket, S., Ajani, J. A., Ewer, M., and Bodey, G. P. (1984). Phase I Clinical Investigation of Homoharringtonine. Cancer Treat. Rep. 68 (9), 1085-1091.

Li, C., Dong, L., Su, R., Bi, Y., Qing, Y., Deng, X., et al. (2020a). Homoharringtonine Exhibits Potent Anti-tumor Effect and Modulates DNA Epigenome in Acute Myeloid Leukemia by Targeting SP1/TET1/5hmC. Haematologica 105 (1), 148-160. doi:10.3324/haematol.2018.208835

Li, M., Shi, F., Fei, X., Wu, S., Wu, D., Pan, M., et al. (2017). PEGylated LongCirculating Liposomes Deliver Homoharringtonine to Suppress Multiple Myeloma Cancer Stem Cells. Exp. Biol. Med. (Maywood) 242 (9), 996-1004. doi:10.1177/1535370216685008

Li, S., Bo, Z., Jiang, Y., Song, X., Wang, C., and Tong, Y. (2020b). Homoharringtonine Promotes BCR-ABL D-egradation through the P-62mediated A-utophagy P-athway. Oncol. Rep. 43 (1), 113-120. doi:10.3892/ or.2019.7412

Li, W., Shao, Y., Hu, L., Zhang, X., Chen, Y., Tong, L., et al. (2007). BM6, a New Semi-synthetic Vinca Alkaloid, Exhibits its Potent in Vivo Anti-tumor Activities via its High Binding Affinity for Tubulin and Improved Pharmacokinetic Profiles. Cancer Biol. Ther. 6 (5), 787-794. doi:10.4161/ cbt.6.5.4006

Li, Y. F., Deng, Z., Din, B. H., and Zhu, J. B. (2012). Effect of Homoharringtonine on Bone Marrow CD34 + CD117 + Cells in Patients with Chronic Myelogenous Leukemia. Leuk. Lymphoma 53 (5), 934-939. doi:10.3109/ 10428194.2011.635859

Li, Z., Chen, Y., An, T., Liu, P., Zhu, J., Yang, H., et al. (2019). Nuciferine Inhibits the Progression of Glioblastoma by Suppressing the SOX2-Akt/stat3-Slug Signaling Pathway. J. Exp. Clin. Cancer Res. 38 (1), 139. doi:10.1186/s13046019-1134-y 
Liu, H., Song, J., Zhou, Y., Cao, L., Gong, Y., Wei, Y., et al. (2019a). Methylxanthine Derivatives Promote Autophagy in Gastric Cancer Cells Targeting PTEN. Anticancer Drugs 30 (4), 347-355. doi:10.1097/CAD.0000000000000724

Liu, L., Fan, J., Ai, G., Liu, J., Luo, N., Li, C., et al. (2019b). Berberine in Combination with Cisplatin Induces Necroptosis and Apoptosis in Ovarian Cancer Cells. Biol. Res. 52 (1), 37-14. doi:10.1186/s40659-019-0243-6

Liu, R. M., Xu, P., Chen, Q., Feng, S. L., and Xie, Y. (2020a). A Multiple-Targets Alkaloid Nuciferine Overcomes Paclitaxel-Induced Drug Resistance In Vitro and In Vivo. Phytomedicine 79, 153342. doi:10.1016/j.phymed.2020.153342

Liu, X., Ji, Q., Ye, N., Sui, H., Zhou, L., Zhu, H., et al. (2015). Berberine Inhibits Invasion and Metastasis of Colorectal Cancer Cells via COX-2/PGE2 Mediated JAK2/STAT3 Signaling Pathway. PLoS One 10 (5), e0123478. doi:10.1371/journal.pone.0123478

Liu, X., Zhang, Y., Wu, S., Xu, M., Shen, Y., Yu, M., et al. (2020b). Palmatine Induces G2/M Phase Arrest and Mitochondrial-Associated Pathway Apoptosis in Colon Cancer Cells by Targeting AURKA. Biochem. Pharmacol. 175, 113933. doi:10.1016/j.bcp.2020.113933

Lu, J.-J., Bao, J.-L., Chen, X.-P., Huang, M., and Wang, Y.-T. (2012). "Alkaloids Isolated from Natural Herbs as the Anticancer Agents." Review Article. Evidence-Based Complement. Altern. MedicineSeptember 4, 2012.

Luo, C. Y., Tang, J. Y., and Wang, Y. P. (2004). Homoharringtonine: A New Treatment Option for Myeloid Leukemia. Hematology 9 (4), 259-270. doi:10.1080/10245330410001714194

Ma, W. K., Li, H., Dong, C. L., He, X., Guo, C. R., Zhang, C. F., et al. (2016). Palmatine from Mahonia Bealei Attenuates Gut Tumorigenesis in ApcMin/+ Mice via Inhibition of Inflammatory Cytokines. Mol. Med. Rep. 14 (1), 491-498. doi: $10.3892 / \mathrm{mmr} .2016 .5285$

Maia, E. H. B., Assis, L. C., de Oliveira, T. A., da Silva, A. M., and Taranto, A. G. (2020). Structure-Based Virtual Screening: From Classical to Artificial Intelligence. Front. Chem. 8, 343. doi:10.3389/fchem.2020.00343

Mohammadzadeh, N., Mehri, S., and Hosseinzadeh, H. (2017). Berberis Vulgaris and its Constituent Berberine as Antidotes and Protective Agents against Natural or Chemical Toxicities. Iran J. Basic Med. Sci. 20 (5), 538-551. doi:10.22038/IJBMS.2017.8678

Mongraw-Chaffin, M. L., Cohn, B. A., Cohen, R. D., and Christianson, R. E. (2008). Maternal Smoking, Alcohol Consumption, and Caffeine Consumption during Pregnancy in Relation to a Son's Risk of Persistent Cryptorchidism: a Prospective Study in the Child Health and Development Studies Cohort, 1959-1967. Am. J. Epidemiol. 167 (3), 257-261. doi:10.1093/aje/kwm311

Neidhart, J. A., Young, D. C., Howinstein, E. B., and Metz, E. N. (1986). Phase I Trial of Homoharringtonine Administered by Prolonged Continuous Infusion. Cancer Res. 46 (2), 967-969.

Neuwinger, H. D. (1996). African Ethnobotany: Poisons and Drugs: Chemistry, Pharmacology, Toxicology. Weinheim: CRC Press.

Newman, K. N., Meeks, R. G., and Denine, E. P. (1981). Final Phase II Report of Task I: Preclinical Intravenous Toxicity Study of Homoharringtonine (NSC: 141633) in CDF, Mice and Beagle Dogs. Bethesda: The Division of Cancer Treatment, National Cancer Institute.

Ni, D., Ho, D. H., Vijjeswarapu, M., Felix, E., Rhea, P. R., and Newman, R. A. (2003). Metabolism of Homoharringtonine, a Cytotoxic Component of the Evergreen Plant Cephalotaxus Harringtonia. J. Exp. Ther. Oncol. 3 (1), 47-52. doi:10.1046/j.1359-4117.2003.01066.x

Nugraha, A. S., Haritakun, R., Dillon, C. T., Lambert, J. M., Dillon, C. T., and Keller, P. A. (2021). Alkaloids from the Root of Indonesian Annona Muricata L. Nat. Prod. Res. 35 (3), 481-489. doi:10.1080/14786419.2019.1638380

Peng, Z., Guan, Q., Luo, J., Deng, W., Liu, J., Yan, R., et al. (2020). Sophoridine Exerts Tumor-Suppressive Activities via Promoting ESRRG-Mediated $\beta$-catenin Degradation in Gastric Cancer. BMC Cancer 20 (1), 1-12. doi:10.1186/s12885-020-07067-x

Pérez-Pérez, D., Reyes-Vidal, I., Chávez-Cortez, E. G., Sotelo, J., and MagañaMaldonado, R. (2019). Methylxanthines: Potential Therapeutic Agents for Glioblastoma. Pharmaceuticals 12 (3), 130.

Prada-Gracia, D., Huerta-Yépez, S., and Moreno-Vargas, L. M. (2016). Application of Computational Methods for Anticancer Drug Discovery, Design, and Optimization. Boletín Médico Del. Hosp. Infantil de México (English Edition) 73 (6), 411-423. doi:10.1016/j.bmhime.2017.11.040

Rad, S. Z. K., Rameshrad, M., and Hosseinzadeh, H. (2017). Toxicology Effects of Berberis Vulgaris (Barberry) and its Active Constituent, Berberine: A Review. Iran J. Basic Med. Sci. 20 (5), 516-529. doi:10.22038/IJBMS.2017.8676
Rahman, M. A., Bulbul, M. R. H., and Kabir, Y. (2020). "Plant-Based Products in Cancer Prevention and Treatment," in Functional Foods in Cancer Prevention and Therapy (Elsevier), 237-259. doi:10.1016/b978-0-12-816151-7.00013-2

Rosendahl, A. H., Perks, C. M., Zeng, L., Markkula, A., Simonsson, M., Rose, C., et al. (2015). Caffeine and Caffeic Acid Inhibit Growth and Modify Estrogen Receptor and Insulin-like Growth Factor I Receptor Levels in Human Breast Cancer. Clin. Cancer Res. 21 (8), 1877-1887. doi:10.1158/1078-0432.CCR-141748

Ruan, H., Zhan, Y. Y., Hou, J., Xu, B., Chen, B., Tian, Y., et al. (2017). Berberine Binds RXRa to Suppress $\beta$-catenin Signaling in colon Cancer Cells. Oncogene 36 (50), 6906-6918. doi:10.1038/onc.2017.296

Schmidt, R. J., Romitti, P. A., Burns, T. L., Browne, M. L., Druschel, C. M., Olney, R. S., et al. (2009). Maternal Caffeine Consumption and Risk of Neural Tube Defects. Birth Defects Res. A. Clin. Mol. Teratol 85 (11), 879-889. doi:10.1002/ bdra.20624

Shi, X., Zhu, M., Gong, Z., Yang, T., Yu, R., Wang, J., et al. (2020). Homoharringtonine Suppresses LoVo Cell Growth by Inhibiting EphB4 and the PI3K/AKT and MAPK/EKR1/2 Signaling Pathways. Food Chem. Toxicol. 136, 110960. doi:10.1016/j.fct.2019.110960

Shi, Y., Ye, J., Yang, Y., Zhao, Y., Shen, H., Ye, X., et al. (2021). The Basic Research of the Combinatorial Therapy of ABT-199 and Homoharringtonine on Acute Myeloid Leukemia. Front. Oncol. 1, 2747. doi:10.3389/ fonc.2021.692497

Soleymankhani, M., Sigaroodi, F., Khalighi, R., Hajiaghaee, B. H., Naghdi, A. M., and Nohooji, M. G. (2015). A Systematic Review on Main Chemical Constituents of Papaver Bracteatum. Journal of Medicinal Plants 14 (53), 6-14.

Song, C. M., Lim, S. J., and Tong, J. C. (2009). Recent Advances in Computer-Aided Drug Design. Brief Bioinform 10 (5), 579-591. doi:10.1093/bib/bbp023

Sun, Q., Li, S., Li, J., Fu, Q., Wang, Z., Li, B., et al. (2018a). Homoharringtonine Regulates the Alternative Splicing of Bcl-X and Caspase 9 through a Protein Phosphatase 1-Dependent Mechanism. BMC Complement. Altern. Med. 18 (1), 1-11. doi:10.1186/s12906-018-2233-6

Sun, Y., Yu, J., Liu, X., Zhang, C., Cao, J., Li, G., et al. (2018b). Oncosis-like Cell Death Is Induced by Berberine through ERK1/2-Mediated Impairment of Mitochondrial Aerobic Respiration in Gliomas. Biomed. Pharmacother. 102, 699-710. doi:10.1016/j.biopha.2018.03.132

Sung, H., Ferlay, J., Siegel, R. L., Laversanne, M., Soerjomataram, I., Jemal, A., et al. (2021). Global Cancer Statistics 2020: GLOBOCAN Estimates of Incidence and Mortality Worldwide for 36 Cancers in 185 Countries. CA A. Cancer J. Clin. 71 (3), 209-249. doi:10.3322/caac. 21660

Tian, B., Tian, M., and Huang, S. M. (2020). Advances in Phytochemical and Modern Pharmacological Research of Rhizoma Corydalis. Pharm. Biol. 58 (1), 265-275. doi:10.1080/13880209.2020.1741651

Tilaoui, M., MouseMouse, H. A., Jaafari, A., and Zyad, A. (2014). Differential Effect of Artemisinin against Cancer Cell Lines. Nat. Prod. Bioprospect 4 (3), 189-196. doi:10.1007/s13659-014-0024-4

Tiwari, R., Mahasenan, K., Pavlovicz, R., Li, C., and Tjarks, W. (2009). Carborane Clusters in Computational Drug Design: A Comparative Docking Evaluation Using AutoDock, FlexX, Glide, and Surflex. J. Chem. Inf. Model. 49 (6), 1581-1589. doi:10.1021/ci900031y

Tuzimski, T., Petruczynik, A., Kaproń, B., Makuch-Kocka, A., Szultka-Młyńska, M., Misiurek, J., et al. (2021). Determination of Cytotoxic Activity of Selected Isoquinoline Alkaloids and Plant Extracts Obtained from Various Parts of Mahonia Aquifolium Collected in Various Vegetation Seasons. Molecules 26 (4), 816. doi:10.3390/molecules 26040816

Ur Rashid, H., Rasool, S., Ali, Y., Khan, K., and Martines, M. A. U. (2020). AntiCancer Potential of Sophoridine and its Derivatives: Recent Progress and Future Perspectives. Bioorg. Chem. 99, 103863. doi:10.1016/j.bioorg.2020.103863

Venkata Charan Tej, G. N., Neogi, K., Verma, S. S., Chandra Gupta, S., and Nayak, P. K. (2019). Caffeine-Enhanced Anti-tumor Immune Response through Decreased Expression of PD1 on Infiltrated Cytotoxic T Lymphocytes. Eur. J. Pharmacol. 859, 172538. doi:10.1016/j.ejphar.2019.172538

Wan, L., Zhao, Y., Zhang, Q., Gao, G., Zhang, S., Gao, Y., et al. (2019). Alkaloid Extract of Corydalis Yanhusuo Inhibits Angiogenesis via Targeting Vascular Endothelial Growth Factor Receptor Signaling. BMC Complement. Altern. Med. 19 (1), 1-13. doi:10.1186/s12906-019-2739-6

Wang, C., Wang, H., Zhang, Y., Guo, W., Long, C., Wang, J., et al. (2017a). Berberine Inhibits the Proliferation of Human Nasopharyngeal Carcinoma 
Cells via an Epstein-Barr Virus Nuclear Antigen 1-Dependent Mechanism. Oncol. Rep. 37 (4), 2109-2120. doi:10.3892/or.2017.5489

Wang, J., Yang, S., Cai, X., Dong, J., Chen, Z., Wang, R., et al. (2016). Berberine Inhibits EGFR Signaling and Enhances the Antitumor Effects of EGFR Inhibitors in Gastric Cancer. Oncotarget 7 (46), 76076-76086. doi:10.18632/ oncotarget. 12589

Wang, L., Zhao, L., Wei, G., Saur, D., Seidler, B., Wang, J., et al. (2018). Homoharringtonine Could Induce Quick Protein Synthesis of PSMD11 through Activating MEK1/ERK1/2 Signaling Pathway in Pancreatic Cancer Cells. J. Cell Biochem 119 (8), 6644-6656. doi:10.1002/jcb.26847

Wang, L. B., Wang, D. N., Wu, L. G., Cao, J., Tian, J. H., Liu, R., et al. (2021). Homoharringtonine Inhibited Breast Cancer Cells Growth via MiR-18a-3p/ AKT/MTOR Signaling Pathway. Int. J. Biol. Sci. 17 (4), 995-1009. doi:10.7150/ ijbs.44907

Wang, Q., Ding, W., Ding, Y., Ma, J., Qian, Z., Shao, J., et al. (2017b). Homoharringtonine Suppresses Imatinib Resistance via the Bcl-6/P53 Pathway in Chronic Myeloid Leukemia Cell Lines. Oncotarget 8 (23), 37594-37604. doi:10.18632/oncotarget.16731

Wang, Y., and Zhang, S. (2018). Berberine Suppresses Growth and Metastasis of Endometrial Cancer Cells via MiR-101/COX-2. Biomed. Pharmacother. 103, 1287-1293. doi:10.1016/j.biopha.2018.04.161

Weng, T. Y., Wu, H. F., Li, C. Y., Hung, Y. H., Chang, Y. W., Chen, Y. L., et al. (2018). Homoharringtonine Induced Immune Alteration for an Efficient Antitumor Response in Mouse Models of Non-small Cell Lung Adenocarcinoma Expressing Kras Mutation. Sci. Rep. 8 (1), 1-11. doi:10.1038/s41598-01826454-w

Weng, X., Odouli, R., and Li, D. K. (2008). Maternal Caffeine Consumption during Pregnancy and the Risk of Miscarriage: A Prospective Cohort Study. Am. J. Obstet. Gynecol. 198 (3), 279-286. doi:10.1016/ j.ajog.2007.10.803

Xiong, D. D., Feng, Z. B., Lai, Z. F., Qin, Y., Liu, L. M., Fu, H. X., et al. (2019). High Throughput CircRNA Sequencing Analysis Reveals Novel Insights into the Mechanism of Nitidine Chloride against Hepatocellular Carcinoma. Cell Death Dis 10 (9), 1-16. doi:10.1038/s41419-019-1890-9

Xu, X., Yi, H., Wu, J., Kuang, T., Zhang, J., Li, Q., et al. (2021). Therapeutic Effect of Berberine on Metabolic Diseases: Both Pharmacological Data and Clinical Evidence. Biomed. Pharmacother. 133, 110984. doi:10.1016/ j.biopha.2020.110984

Yakhni, M., Briat, A., El Guerrab, A., Furtado, L., Kwiatkowski, F., Miot-Noirault, E., et al. (2019). Homoharringtonine, an Approved Anti-leukemia Drug, Suppresses Triple Negative Breast Cancer Growth through a Rapid Reduction of Anti-apoptotic Protein Abundance. Am. J. Cancer Res. 9 (5), 1043-1060.

Yi, J., Ye, X., Wang, D., He, K., Yang, Y., Liu, X., et al. (2013). Safety Evaluation of Main Alkaloids from Rhizoma Coptidis. J. Ethnopharmacol 145 (1), 303-310. doi:10.1016/j.jep.2012.10.062

Yongji, Z., Hui, Y., Xueying, L., Yongxing, Z., Wenjun, L., Xueli, L., et al. (1979). Experimental Studies on the Toxicity of Harringtonine and Homoharringtonine. Chin. Med. J. (Engl) 92 (3), 175-180.

Yu, M., Ren, L., Liang, F., Zhang, Y., Jiang, L., Ma, W., et al. (2020). Effect of Epiberberine from Coptis Chinensis Franch on Inhibition of Tumor Growth in MKN-45 Xenograft Mice. Phytomedicine 76, 153216. doi:10.1016/ j.phymed.2020.153216

Yuan, Y., Chen, J., Wang, J., Xu, M., Zhang, Y., Sun, P., et al. (2020). Identification Hub Genes in Colorectal Cancer by Integrating Weighted Gene Co-expression Network Analysis and Clinical Validation In Vivo and Vitro. Front. Oncol. 10, 638. doi:10.3389/fonc.2020.00638

Zhang, H., Wang, G., Jiang, B., Cao, M., Jiang, Q., Yin, L., et al. (2020a). The Knowledge, Attitude, and Self-Reported Behaviors of Oncology Physicians Regarding Fertility Preservation in Adult Cancer Patients. J. Cancer Educ. 35 (6), 1119-1127. doi:10.1007/s13187-019-01567-6
Zhang, J., He, S., Wang, J., Wang, C., Wu, J., Wang, W., et al. (2020b). A Review of the Traditional Uses, Botany, Phytochemistry, Pharmacology, Pharmacokinetics, and Toxicology of Corydalis Yanhusuo. Nat. Product. Commun. 15 (9), 1934578X20957752. doi:10.1177/1934578x20957752

Zhang, P., Wang, Q., Lin, Z., Yang, P., Dou, K., and Zhang, R. (2019). Berberine Inhibits Growth of Liver Cancer Cells by Suppressing Glutamine Uptake. Onco Targets Ther. 12, 11751-11763. doi:10.2147/OTT.S235667

Zhang, Q., Wang, X., Cao, S., Sun, Y., He, X., Jiang, B., et al. (2020c). Berberine Represses Human Gastric Cancer Cell Growth In Vitro and In Vivo by Inducing Cytostatic Autophagy via Inhibition of MAPK/MTOR/P70S6K and Akt Signaling Pathways. Biomed. Pharmacother. 128, 110245. doi:10.1016/ j.biopha.2020.110245

Zhang, Z., Zhou, L., Xie, N., NiceNice, E. C., Zhang, T., Cui, Y., et al. (2020d). Overcoming Cancer Therapeutic Bottleneck by Drug Repurposing. Signal. Transduct Target. Ther. 5 (1), 113-125. doi:10.1038/s41392-020-00213-8

Zhao, B., Hui, X., Zeng, H., Yin, Y., Huang, J., Tang, Q., et al. (2021). Sophoridine Inhibits the Tumour Growth of Non-small Lung Cancer by Inducing Macrophages M1 Polarisation via MAPK-Mediated Inflammatory Pathway. Front. Oncol. 11, 634851. doi:10.3389/fonc.2021.634851

Zhao, Y., Jing, Z., Lv, J., Zhang, Z., Lin, J., Cao, X., et al. (2017). Berberine Activates Caspase-9/Cytochrome C-Mediated Apoptosis to Suppress Triple-Negative Breast Cancer Cells In Vitro and In Vivo. Biomed. Pharmacother. 95, 18-24. doi:10.1016/j.biopha.2017.08.045

Zhou, H., XuXu, R. Z., Gu, Y., Shi, P. F., and Qian, S. (2020). Targeting of PhosphoEif4e by Homoharringtonine Eradicates a Distinct Subset of Human Acute Myeloid Leukemia. Leuk. Lymphoma 61 (5), 1084-1096. doi:10.1080/ 10428194.2017.1390229

Zhu, M., Gong, Z., Wu, Q., Su, Q., Yang, T., Yu, R., et al. (2020). Homoharringtonine Suppresses Tumor Proliferation and Migration by Regulating EphB4-Mediated $\beta$-catenin Loss in Hepatocellular Carcinoma. Cell Death Dis 11 (8), 1-13. doi:10.1038/s41419-020-02902-2

Zhuang, H., Dai, X., Zhang, X., Mao, Z., and Huang, H. (2020). Sophoridine Suppresses Macrophage-Mediated Immunosuppression through TLR4/IRF3 Pathway and Subsequently Upregulates CD8+ T Cytotoxic Function against Gastric Cancer. Biomed. Pharmacother. 121, 109636. doi:10.1016/ j.biopha.2019.109636

Zishan, M., Saidurrahman, S., Anayatullah, A., Azeemuddin, A., Ahmad, Z., and Hussain, M. W. (2017). Natural Products Used as Anti-cancer Agents. J. Drug Deliv. Ther. 7 (3), 11-18. doi:10.22270/jddt.v7i3.1443

Zou, Y., Wang, X., Sims, J., Wang, B., Pandey, P., Welsh, C. L., et al. (2019). Computationally Assisted Discovery and Assignment of a Highly Strained and PANC-1 Selective Alkaloid from Alaska's Deep Ocean. J. Am. Chem. Soc. 141 (10), 4338-4344. doi:10.1021/jacs.8b11403

Conflict of Interest: The authors declare that the research was conducted in the absence of any commercial or financial relationships that could be construed as a potential conflict of interest.

Publisher's Note: All claims expressed in this article are solely those of the authors and do not necessarily represent those of their affiliated organizations, or those of the publisher, the editors, and the reviewers. Any product that may be evaluated in this article, or claim that may be made by its manufacturer, is not guaranteed or endorsed by the publisher.

Copyright (ㄷ 2021 Tilaoui, Ait Mouse and Zyad. This is an open-access article distributed under the terms of the Creative Commons Attribution License (CC BY). The use, distribution or reproduction in other forums is permitted, provided the original author(s) and the copyright owner(s) are credited and that the original publication in this journal is cited, in accordance with accepted academic practice. No use, distribution or reproduction is permitted which does not comply with these terms. 


\section{GLOSSARY}

5hmC 5-hydroxymethylcytosine

ABCG2 ATP-binding cassette transporter G2

ABL Abelson proto-oncogene

AIF Apoptosis-inducing factor

AKT Protein kinase B

AMPK AMP-activated protein kinase

AP-2 Adapter protein complex 2

ARE Antioxidant response element

ATG Autophagy-related protein

AURKA Aurora kinase A

BCR Breakpoint cluster region gene

BCRP Breast cancer resistance protein

COL1 A1 Collagen, type I, alpha 1

DIABLO Direct IAP binding protein with low $\mathrm{pI}$

eIF4E Eukaryotic translation initiation factor $4 \mathrm{E}$

EphB4 Ephrin type-B receptor 4

ER Endoplasmic reticulum

ERK Extracellular signal-regulated kinase

FAK Focal adhesion kinase

FLICE Fas-associated death domain-like interleukin-1 $\beta$-converting enzyme

FOXO1 Forkhead box O1

GRP78 Glucose-regulated protein 78

GSK3B Glycogen synthase kinase 3

HIF-1 $\alpha$ Hypoxia-inducible factor $-1 \alpha$

HMGR 3-hydroxy-3-methylglutaryl-coenzyme A reductase

HOXA9 Homeobox A9

hTERT Human telomerase reverse transcriptase

IAP Inhibitor of apoptosis protein

iPLA2 Independent phospholipase A2

IRF3 Interferon-responsive factor 3

JNKs c-Jun $\mathrm{N}$-terminal kinases

LATS Large tumor suppressor

LC3 Microtubule-associated protein 1A/1B-light chain 3

LOX-5 5-lipoxygenase

LTB4 Leukotriene B4

MAPKs Mitogen-activated protein kinases

MCL-1 Myeloid-cell leukemia 1
MDM2 Mouse double minute 2 homolog

Meis1 Myeloid ecotropic viral integration site 1

MMPs Matrix metalloproteinases

mTOR Mammalian target of rapamycin

NOSs Nitric oxide synthases

Nrf2 Nuclear erythroid 2-related factor 2

PARPs Poly (ADP-ribose) polymerases

PD-1 Programmed cell death 1

PDE4 Phosphodiesterase 4

PDGF Platelet-derived growth factor

PI3Ks Phosphoinositide 3-kinases

PSMD1 26S proteasome non-ATPase regulatory subunit 1

PTEN Phosphatase and tensin homolog

RANKL Receptor activator of nuclear factor kappa-B ligand

RAPK Rho-associated protein kinase

RAR Retinoic acid receptor alpha

ROCK Rho-associated coiled-coil kinase

RPS6 Ribosomal protein S6

RTKs Receptor tyrosine kinases

SCAP SREBP cleavage-activating protein

SHH Sonic hedgehog

SMAC Second mitochondria-derived activator of caspase

SMAD3 Mothers against decapentaplegic homolog 3

Sp1 Specificity protein 1

SREBF1 Sterol regulatory element-binding protein 1

SRSF3 Ser/Arg-rich splicing factor 3

STAT3 Signal transducer and activator of transcription 3

TET1 Tet methylcytosine dioxygenase

TGF- $\boldsymbol{\beta}$ Transforming growth factor beta

TLR4 Toll-like receptor 4

ULK1 Unc-51-like kinase-1

uPA Urokinase-type plasminogen activator

VEGF Vascular endothelial growth factor

Vps34 Vacuolar protein sorting 34

WEE1 Wee1-like protein kinase

YAP Yes-associated protein 1

ZEB Zinc finger e-box-binding homeobox

ZFX Zinc finger protein $x$-linked

ZO1 Zonula occludens-1 (Tight junction protein-1) 